University of Nebraska - Lincoln

DigitalCommons@University of Nebraska - Lincoln

\title{
Influence of plankton mercury dynamics and trophic pathways on mercury concentrations of top predator fish of a mining-impacted reservoir
}

\author{
A. Robin Stewart \\ U.S. Geoloical Survey, arstewar@usgs.gov \\ Michael K. Saiki \\ U.S. Geoloical Survey \\ James S. Kuwabara \\ U.S. Geoloical Survey \\ Charles N. Alpers \\ U.S. Geoloical Survey \\ Mark Marvin-DiPasquale \\ U.S. Geoloical Survey, mmarvin@usgs.gov \\ See next page for additional authors \\ Follow this and additional works at: https://digitalcommons.unl.edu/usgsstaffpub \\ Part of the Earth Sciences Commons
}

Stewart, A. Robin; Saiki, Michael K.; Kuwabara, James S.; Alpers, Charles N.; Marvin-DiPasquale, Mark; and Krabbenhoft, David P., "Influence of plankton mercury dynamics and trophic pathways on mercury concentrations of top predator fish of a mining-impacted reservoir" (2008). USGS Staff -- Published Research. 474.

https://digitalcommons.unl.edu/usgsstaffpub/474

This Article is brought to you for free and open access by the US Geological Survey at DigitalCommons@University of Nebraska - Lincoln. It has been accepted for inclusion in USGS Staff -- Published Research by an authorized administrator of DigitalCommons@University of Nebraska - Lincoln. 


\section{Authors}

A. Robin Stewart, Michael K. Saiki, James S. Kuwabara, Charles N. Alpers, Mark Marvin-DiPasquale, and David P. Krabbenhoft 


\title{
Influence of plankton mercury dynamics and trophic pathways on mercury concentrations of top predator fish of a mining-impacted reservoir
}

\author{
A. Robin Stewart, Michael K. Saiki, James S. Kuwabara, Charles N. Alpers, \\ Mark Marvin-DiPasquale, and David P. Krabbenhoft
}

\begin{abstract}
Physical and biogeochemical characteristics of the aquatic environment that affect growth dynamics of phytoplankton and the zooplankton communities that depend on them may also affect uptake of methylmercury (MeHg) into the pelagic food web of oligotrophic reservoirs. We evaluated changes in the quality and quantity of suspended particulate material, zooplankton taxonomy, and $\mathrm{MeHg}$ concentrations coincident with seasonal changes in water storage of a mining-impacted reservoir in northern California, USA. MeHg concentrations in bulk zooplankton increased from $4 \mathrm{ng} \cdot \mathrm{g}^{-1}$ at low water to $77 \pm 6.1 \mathrm{ng} \cdot \mathrm{g}^{-1}$ at high water and were positively correlated with cladoceran biomass $(r=$ $0.66)$ and negatively correlated with rotifer biomass $(r=-0.65)$. Stable isotope analysis revealed overall higher $\mathrm{MeHg}$ concentrations in the pelagic-based food web relative to the benthic-based food web. Statistically similar patterns of trophic enrichment of $\mathrm{MeHg}$ (slopes) for the pelagic and benthic food webs and slightly higher $\mathrm{MeHg}$ concentrations in zooplankton than in benthic invertebrates suggest that the difference in $\mathrm{MeHg}$ bioaccumulation among trophic pathways is set at the base of the food webs. These results suggest an important role for plankton dynamics in driving the $\mathrm{MeHg}$ content of zooplankton and ultimately $\mathrm{MeHg}$ bioaccumulation in top predators in pelagic-based food webs.

Résumé : Les caractéristiques physiques et biogéochimiques du milieu aquatique qui affectent la dynamique de la croissance du phytoplancton et les communautés zooplanctoniques qui en dépendent peuvent aussi influencer l'introduction de méthylmercure $(\mathrm{MeHg})$ dans le réseau alimentaire pélagique des réservoirs oligotrophes. Nous déterminons les changements dans la qualité et la quantité des matières particulaires en suspension, dans la taxonomie du zooplancton et dans les concentrations de $\mathrm{MeHg}$ qui coïncident avec les changements saisonniers d'emmagasinement d'eau dans un réservoir affecté par des activités minières dans le nord de la Californie, É.-U. Les concentrations de MeHg dans le zooplancton global augmentent de $4 \mathrm{ng} \cdot \mathrm{g}^{-1}$ aux basses eaux à $77 \pm 6,1 \mathrm{ng} \cdot \mathrm{g}^{-1}$ aux hautes eaux et elles sont en corrélation positive avec la biomasse des cladocères $(r=0,66)$ et en corrélation négative avec la biomasse des rotifères $(r=-0,65)$. Une analyse des isotopes stables indique des concentrations globalement plus élevées de $\mathrm{MeHg}$ dans le réseau alimentaire pélagique que dans le réseau alimentaire benthique. Les patrons statistiquement semblables d'enrichissement trophique de $\mathrm{MeHg}$ (pentes) dans les réseaux alimentaires pélagiques et benthiques et des concentrations légèrement supérieures de $\mathrm{MeHg}$ dans le zooplancton par rapport aux invertébrés benthiques font penser que la différence de bioconcentration de $\mathrm{MeHg}$ entre les voies trophiques s'établit dès la base des réseaux alimentaires. Ces résultats indiquent un rôle important joué par la dynamique du plancton dans le contenu en $\mathrm{MeHg}$ du zooplanction et, en fin de compte, dans la bioconcentration de $\mathrm{MeHg}$ chez les prédateurs supérieurs dans les réseaux alimentaires pélagiques.
\end{abstract}

[Traduit par la Rédaction]

\section{Introduction}

Mercury accumulation at the base of aquatic food webs typically leads to elevated mercury concentrations in fish that threaten aquatic wildlife as well as human consumers. Despite a growing knowledge of widespread mercury con- tamination, there is still uncertainty surrounding $(i)$ the relative importance of critical abiotic and biotic processes (as well as their interactions) that control mercury bioaccumulation and (ii) how these processes might be managed to effectively reduce mercury levels in fish. The planktonic food web of lakes and reservoirs is a critical entry point for mer-

\footnotetext{
Received 14 September 2007. Accepted 18 April 2008. Published on the NRC Research Press Web site at cjfas.nrc.ca on 14 October

2008.

J20173

A.R. Stewart. ${ }^{1}$ US Geological Survey (USGS), MS 496, 345 Middlefield Road, Menlo Park, CA 94025, USA.

M.K. Saiki. USGS, Western Fisheries Research Center, Dixon Duty Station, 6924 Tremont Road, Dixon, CA 95620, USA.

J.S. Kuwabara. USGS, MS 439, 345 Middlefield Road, Menlo Park, CA 94025, USA.

C.N. Alpers. USGS, California Water Science Center, 6000 J Street, Sacramento, CA 95819, USA

M. Marvin-DiPasquale. USGS, MS 480, 345 Middlefield Road, Menlo Park, CA 94025, USA.

D.P. Krabbenhoft. USGS, 8505 Research Way, Middleton, WI 53562, USA.

${ }^{1}$ Corresponding author (e-mail: arstewar@usgs.gov).
} 
cury into the pelagic food web. Aqueous methylmercury (MeHg), the most biologically available form of mercury, is concentrated a million-fold by microscopic particles in the water column, including phytoplankton and bacteria (Mason et al. 1996; Miles et al. 2001). These MeHg-enriched particles are then consumed by zooplankton, which in turn are a primary food source of larval, juvenile, and some adult fish (Hall et al. 1997). Not surprisingly, uptake of $\mathrm{MeHg}$ into the planktonic food web has been shown to be tightly linked to aqueous $\mathrm{MeHg}$ concentrations (Paterson et al. 1998; St. Louis et al. 2004), which are in turn regulated by a series of abiotic and microbial processes. However, recent studies suggest that other biological processes such as the dynamics of phytoplankton communities (Plourde et al. 1997; Montgomery et al. 2000; Kainz and Mazumder 2005) may also be important. As phytoplankton grow, they accumulate aqueous $\mathrm{MeHg}$ at maximal bioconcentration factors and also serve as a food source, supporting the growth of zooplankton communities. Zooplankton species composition has also been shown in some instances to influence $\mathrm{MeHg}$ content of zooplankton communities (Kainz et al. 2002; Kainz and Mazumder 2005). Thus, physical and biogeochemical characteristics of the aquatic environment that affect growth dynamics of phytoplankton and the zooplankton communities that depend on them may also affect uptake of $\mathrm{MeHg}$ into the pelagic food web of reservoirs. Here we examine how seasonal changes in water storage and continued mercury inputs from a mining-impacted upstream watershed influence the temporal-spatial dynamics and mercury content of a planktonic food web as well as mercury burdens in top predator fish.

For decades, research on the effects of reservoir creation (predominantly for energy production or water storage) on mercury cycling in aquatic food webs has identified common processes leading to elevated $\mathrm{Hg}$ in fish (Rosenberg et al. 1997). Newly flooded environments often result in an increase in water column concentrations of $\mathrm{MeHg}$, which is subsequently taken up by phytoplankton and zooplankton. This phenomenon, known as the reservoir effect, is an important consideration in understanding mercury impacts of reservoirs (Bodaly et al. 1984, 2007). The reservoir effect is greatest in newly flooded forested areas (with large surface area to volume ratios; Johnston et al. 1991) and wetlands characterized by terrestrial organic matter and peat, respectively, with the initial spike in water column and biota $\mathrm{MeHg}$ concentrations gradually declining over many years as organic matter decomposes (Rosenberg et al. 1997; Tremblay et al. 1998; Bodaly et al. 2007). In these cases, the quantity and quality of inorganic mercury available for methylation seems to be of less consequence than the amount of natural organic matter. A secondary indirect effect of reservoirs is the impact on the ecology of the planktonic food web as it responds to extreme swings in water level (Campbell et al. 1998) and sources of organic carbon (Paterson et al. 1997). Research indicates the response of the plankton community to new reservoirs is dramatic and complex. Changes have included rapid increases and decreases in phytoplankton production and biomass, depending on water residence times, nutrients, planktonic interactions, as well as increases in bacterial and zooplankton production (Ostrofsky and Duthie 1980; Paterson et al. 1997; Campbell et al.
1998). However, these responses are short-term (years), and their impact on $\mathrm{MeHg}$ accumulation in the planktonic food web appears to be limited relative to increases in aqueous $\mathrm{MeHg}$-associated enhanced methylation (Plourde et al. 1997; Paterson et al. 1998). These dynamics of an attenuated mercury response over time are characteristic of new, persistently flooded reservoirs. But what is the response of managed reservoirs that undergo extreme seasonal changes in water level, causing seasonal reflooding of large areas of terrestrial soils? It is also unclear how continued inputs of aqueous $\mathrm{MeHg}$ and (or) inorganic mercury from upstream contaminated sites, such as those areas receiving atmospheric deposition or anthropogenic mercury wastes (mining or industrial), might influence mercury cycling in reservoirs. Are the quantities of mercury transported into the system and reservoir dynamics important in determining mercury accumulation at the base of the aquatic food web within the reservoir and its transfer up the food chain to sport fish?

The Bear River watershed is located in the heart of the historic gold mining region of the northern Sierra Nevada mountain range of California, USA. Massive quantities of elemental mercury were transported from the nearby Coast Ranges to the Sierra Nevada to extract gold from placer and hard-rock ores, which resulted in substantial transfer of mercury to the environment and contamination of the surrounding watersheds. Camp Far West Reservoir (CFWR) has the highest concentrations of mercury in top predator bass species relative to other reservoirs in the Bear River watershed. Previously reported concentrations of mercury in spotted bass (Micropterus punctulatus) axial muscle from CFWR ranged from 0.58 to $1.5 \mu \mathrm{g} \cdot \mathrm{g}^{-1}$ wet weight $(n=14$, geometric mean $0.92 \mu \mathrm{g} \cdot \mathrm{g}^{-1}$ wet weight), with half the fish having concentrations equal to or greater than the United States Food and Drug Administration action level of $1 \mu \mathrm{g} \cdot \mathrm{g}^{-1}$ wet weight (May et al. 2000). To identify the cause of the high mercury concentrations in sport fish and to identify possible approaches to reduce mercury exposures in fish, a study was initiated to understand mercury dynamics in the reservoir. CFWR undergoes extreme inter- and intra-annual changes in water storage levels $\left(\Delta 1.3 \times 10^{8} \mathrm{~m}^{3}\right)$ and elevation $(\Delta 30 \mathrm{~m})$ and thus has limited, persistent benthic habitat except in the deepest regions of the reservoir and has limited rooted aquatic vegetation, resulting in a dependence on the planktonic food web. We define the planktonic food web as primary producers, bacteria, and suspended organic detrital matter represented by the $0.7-210 \mu \mathrm{m}$ particulate fraction (PF) and zooplankton represented by the bulk $>75 \mu \mathrm{m}$ PF. The objectives of this study were to $(i)$ evaluate the relationship between seasonal changes in water storage and variation in $\mathrm{MeHg}$ concentrations in zooplankton relative to changes in the ecology of the planktonic food web, (ii) determine the relative contribution of pelagic carbon in the CFWR food web, and (iii) evaluate how seasonal variations in the $\mathrm{MeHg}$ content of zooplankton influence trophic enrichment of mercury in a reservoir food web and ultimately the mercury content of sport fish.

\section{Materials and methods}

\section{Site description}

CFWR, located in the lower reach of the Bear River 
Fig. 1. Location of Camp Far West Reservoir (CFWR) and sample sites in northern California, USA. BRA, Bear River arm; MR, midreservoir; ND, near dam; and RCA, Rock Creek arm. Mine locations are from Alpers et al. (2005a) and references therein.

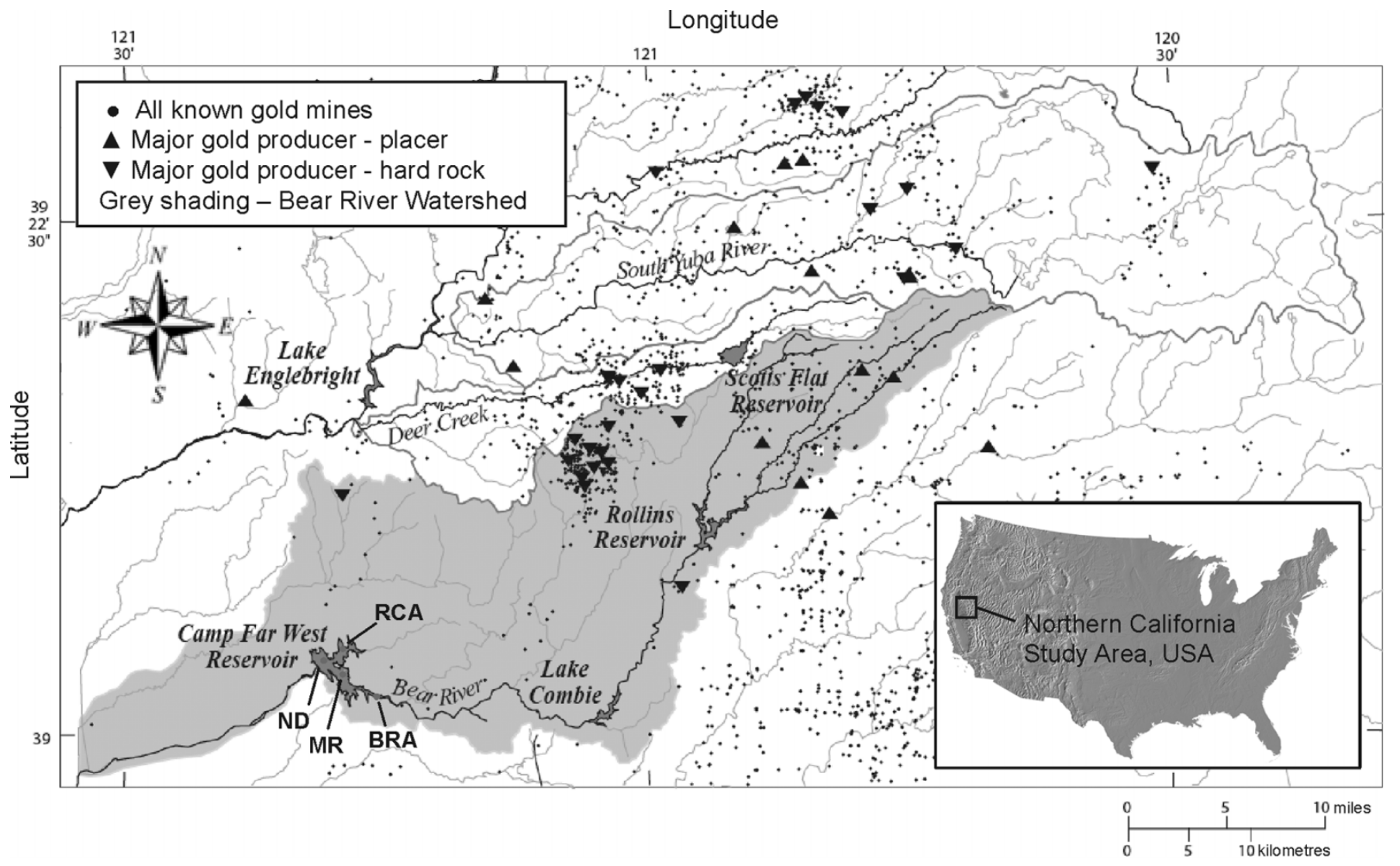

watershed on the western slope of the Sierra Nevada in northern California, was created in 1963 for the purpose of water sales for irrigation (Fig. 1). The hydrology of CFWR is managed to provide a minimum flow of approximately $0.28 \mathrm{~m}^{3} \cdot \mathrm{s}^{-1}$ for fish habitat below the dam during summer and fall. Water sales in summer and early fall, coupled with precipitation variability over multiple time scales, cause dramatic seasonal swings in water storage (up to $94 \%$ drawdown of total capacity of approximately 128 million $\mathrm{m}^{3}$ ) and water elevation (>30 $\mathrm{m}$ of maximum $49 \mathrm{~m}$ depth). CFWR sediments are generally silt-sized and are underlain by bedrock primarily composed of mafic volcanic rocks and pyroclastic sedimentary rocks of Jurassic age (Clark 1976). Auriferous gravels within the upper Bear River watershed were mined extensively from the early 1850 s to the mid-1880s by hydraulic mining methods. This practice included the use of elemental mercury to amalgamate the gold, which resulted in the loss of several million kilograms of mercury to the environment (Alpers et al. 2005a and references therein). Elemental mercury and gold-mercury amalgam can be panned from sediments in the Bear River and mining-impacted tributaries such as Greenhorn Creek (Alpers et al. 2005b). Total mercury concentrations in sediments from abandoned mine sites are as high as $45000 \mu \mathrm{g} \cdot \mathrm{g}^{-1}$ (Alpers et al. 2005b), whereas total mercury in sediments from CFWR range from about 0.3 to $1.0 \mu \mathrm{g} \cdot \mathrm{g}^{-1}$ dry weight (M. Marvin-DiPasquale, unpublished data). Mercury-contaminated sediment continues to be transported in the Bear River watershed and other Sierra
Nevada watersheds affected by historical mining, especially during high-flow events (Alpers et al. 2008).

Three sites in CFWR located along a downstream gradient from the inflow at the Bear River arm to the outflow at the dam were sampled quarterly for 2 years (Fig. 1). These sites were the Bear River arm (BRA), mid-reservoir (MR), and near dam (ND). Because benthic insects were rare at MR, but relatively common in the Rock Creek arm (RCA), additional plankton samples were collected at RCA in the spring of 2003 and summers of 2002 and 2003 for comparison. The range for plankton biomass from RCA was bracketed by those from MR.

\section{Phytoplankton biomass, suspended particulate material, and zooplankton ( $>75 \mu \mathrm{m}$ PF)}

Water samples for analysis of chlorophyll $a$ and analysis of trace elements and stable isotopes ( $\mathrm{C}$ and $\mathrm{N}$ ) in suspended particulate material (SPM) were collected $1 \mathrm{~m}$ below the surface using a Van Dorn water sampler and filtered through a $210 \mu \mathrm{m}$ Nitex mesh to remove coarse particulates (Cloern et al. 2002). Vertical profiles of dissolved oxygen and $\mathrm{pH}$ taken on each sampling trip did not indicate the occurrence of a deep chlorophyll maximum (Alpers et al. 2008), and so it was assumed that surface samples were generally representative of the particles available to grazing zooplankton. Duplicate water samples $(n=2)$ were filtered within $2 \mathrm{~h}$ of collection onto $25 \mathrm{~mm}$ and precombusted $13 \mathrm{~mm}$ glass fiber filters (nominal pore size of $0.7 \mu \mathrm{m}$ ), frozen on dry ice, and then later stored at $-80{ }^{\circ} \mathrm{C}$. Chlorophyll 
$a$ and pheophytin concentrations were determined from the $25 \mathrm{~mm}$ filters fluorometrically (Holm-Hansen and Riemann 1978) within 6 months of collection. The $13 \mathrm{~mm}$ filters holding SPM were moistened with Milli-Q water, fumed in a desiccator with $\mathrm{HCl}$ to remove carbonates, then placed in tin capsules and held in a desiccator until analyzed for carbon and nitrogen isotopes.

Zooplankton were collected by towing a $0.5 \mathrm{~m}$ diameter, $75 \mu \mathrm{m}$ mesh net fitted with a General Oceanics flow meter at an oblique angle from a $12 \mathrm{~m}$ depth to the surface. This approach yielded a spatially integrated sample of zooplankton (both horizontally and vertically, including rotifers) migrating through the epilimnion. The volume of water flowing through the net was recorded, and samples for taxonomicbiomass determinations were carefully washed into sample jars and preserved with Rose Bengal solution. Samples for $\mathrm{MeHg}$ and stable isotope analysis were taken in separate tows, transferred to Teflon jars and frozen at $-20{ }^{\circ} \mathrm{C}$. Samples were freeze-dried, homogenized using a ball mill, then split into subsamples for analysis of $\mathrm{MeHg}$ and stable isotopes.

Zooplankton taxonomic-biomass samples were filtered through a $43 \mu \mathrm{m}$ mesh. Material retained on the mesh was washed into a $1 \mathrm{~L}$ beaker, and water was added to achieve an appropriate dilution of the sample. The sample was then stirred vigorously in a figure-eight pattern to suspend the zooplankton, and a $1 \mathrm{~mL}$ subsample was withdrawn with an automatic pipette and placed in a $1 \mathrm{~mL}$ Sedgewick-Rafter counting slide. Adult copepods and cladocerans were identified to species or genus. The copepodid and naupliar developmental stages of the copepods were identified to species, except for Acanthocyclops and Limnoithona, which were lumped together as cyclopoid nauplii. Rotifers were classified as herbivorous or carnivorous (Asplanchna, Trichocerca, and Synchaeta). The lengths of the first 20 individuals seen in each taxon on each sampling date were measured to $0.1 \mathrm{~mm}$ and averaged. Dry weights were assigned either from literature values or from length $\times$ dry weight regressions. For Pseudodiaptomus forbesi, Synchaeta doerrii, and Limnoithona sinensis dry weights were measured by the California Department of Fish and Game. Eurytemora affinis dry weights were calculated from a regression provided by Cathy Hall, University of California, Davis, California. Acanthocyclops, cladoceran, and rotifer dry weights were determined from Dumont et al. (1975).

\section{Fish and benthic invertebrate sampling}

Fish (threadfin shad (Dorosoma petenense), bluegill (Lepomis macrochirus), and spotted bass) and macroinvertebrates (Chironomidae (midge) larvae, Baetidae (mayfly) nymphs, and virile crayfish (Orconectes virilis)) were collected from the general areas of the BRA, RCA, and ND in August 2002 and 2003 (fish only) and July 2002 (macroinvertebrates only). Fish were measured for total length and weight, scales were removed for age determination, and then fish were individually wrapped in plastic and chilled on wet ice. Individuals for analysis of gut contents were processed within $12 \mathrm{~h}$ by opening the gastrointestinal tracts through dissection to remove gut contents. Skinless fillets were removed from selected fish by dissection, then placed in plastic bags and frozen for mercury analysis. Additional fish were also sampled at roughly bimonthly intervals from May 2002 to August 2003 for gut contents. These additional fish were measured, weighed, and frozen or preserved in $10 \%$ buffered formalin or $70 \%$ isopropyl alcohol.

From each site, composite samples $(n=3)$ of midge larvae and mayfly nymphs weighing at least $2 \mathrm{~g}$ (wet weight) and individual samples $(n=9)$ of crayfish (measured from tip of rostrum to end of telson, then weighed) were collected and frozen in plastic bags for future mercury and isotopic analysis.

\section{Analyses of MeHg and total mercury}

$\mathrm{MeHg}$ concentrations in zooplankton samples $(>75 \mu \mathrm{m}$ PF) were determined by the US Geological Survey Mercury Laboratory (Middleton, Wisconsin), whereas $\mathrm{MeHg}$ in macroinvertebrate samples was determined by Brooks Rand LLC, Seattle, Washington. Total mercury in fish was determined by the US Geological Survey, Columbia, Missouri. Analysis of zooplankton samples was conducted on freeze-dried, homogenized tissues using a distillation/ ethylation/gas-phase separation method with cold vapor atomic fluorescence spectroscopy detection that is based on a method for the determination of $\mathrm{MeHg}$ in filtered and unfiltered waters (DeWild et al. 2002). Samples were weighed out (5-10 mg) into $7 \mathrm{~mL}$ Teflon containers in triplicate, and blanks were included in each sample analysis batch. Frozen samples of fish and macroinvertebrates were ground with a meat grinder and freeze-dried (Virtis Genesis 35EL). MeHg was determined after digestion with $\mathrm{KOH}-$ ethanol followed by aqueous phase ethylation, purge and trap, followed by gas chromatography separation, isothermal decomposition, and analysis by atomic fluorescence detection. Certified reference material for $\mathrm{MeHg}$ from the National Research Council Canada (NRCC) (DORM-2 dogfish muscle) was included in each sample run by the Wisconsin lab and Brooks Rand lab, and values fell within certified ranges. Total mercury was determined with a direct mercury analyzer (Milestone DMA-80). Certified reference materials from National Institute of Standards and Technology (NIST) (Research Material 50 albacore tuna fillet) and NRCC DORM-2 were run with each sample group and fell within certified ranges for total mercury. Method precision, determined from triplicate analysis of seven fish tissue samples, did not exceed $4.4 \%$ relative standard deviation. In all instances, mercury concentrations are reported in dry weight.

\section{Structure of the CFWR food web}

To elucidate feeding relationships among biota in the CFWR food web, tissues of the major invertebrate and fish species were analyzed for stable isotopes. Stable nitrogen isotope ratios $\left(\delta^{15} \mathrm{~N}\right)$ provide a spatially and temporally integrated measure of trophic relationships in a food web (i.e., primary producers $\rightarrow$ invertebrates $\rightarrow$ fish) because $\delta^{15} \mathrm{~N}$ becomes enriched by $2.5 \% 0-5 \%$ between prey and predator (Peterson and Fry 1987). Stable carbon isotope ratios $\left(\delta^{13} \mathrm{C}\right)$ show little or no enrichment $(<1 \%$ ) with each trophic level, but can identify contributions of different foods if foods have distinct isotopic signatures (France 1995).

A subsample of the homogenized tissue analyzed for mercury was taken for stable isotope analysis together with 
bulk $>75 \mu \mathrm{m}$ PF samples, whole body samples of mayfly nymphs, midge larvae, crayfish, and threadfin shad, and skinless fillets of bluegill and spotted bass. Because of the small size of the threadfin shad, dissection of fillet samples was not feasible, so whole body samples were analyzed. Feeding relationships identified using stable isotopes were compared with seasonal analysis of gut contents of the three fish species. Ingested foods from the dissected foregut (esophagus to pyloric sphincter in bluegill and spotted bass or esophagus to gizzard in threadfin shad) were identified under a dissecting microscope, assigned to taxonomic categories, and weighed to determine the relative wet biomass of each category according to Bowen (1997).

Isotope ratios of $\mathrm{C}$ and $\mathrm{N}$ of the seston, $>75 \mu \mathrm{m} \mathrm{PF}$, invertebrates, and fish were determined at the Stable Isotope Facility, University of California, Davis, using a Europa Scientific Hydra 20/20 continuous flow isotope ratio mass spectrometer in conjunction with a Europa ANCA-SL elemental analyzer to convert organic $\mathrm{C}$ and $\mathrm{N}$ into $\mathrm{CO}_{2}$ and $\mathrm{N}_{2}$ gas. Nitrogen isotope samples were standardized against $\mathrm{N}_{2}$ in air as follows:

$$
\delta^{15} \mathrm{~N}(\% \mathrm{o})=\left[\left(R_{\text {sample }} / R_{\text {standard }}\right)-1\right] \times 1000
$$

where $R={ }^{15} \mathrm{~N} /{ }^{14} \mathrm{~N}$. A similar relation for $\delta^{13} \mathrm{C}\left(R={ }^{13} \mathrm{C} /\right.$ ${ }^{12} \mathrm{C}$ ) was used to standardize carbon isotope samples against Pee Dee Belemnite. Instrument precision was $0.1 \%$ for carbon and $0.3 \%$ for nitrogen based on replicate analyses of standard reference materials.

\section{Statistics}

Data were summarized by means \pm 1 standard deviation (SD) unless stated otherwise. Coefficient of variation $(\mathrm{CV}$, $\%$ ) was calculated as $1 \mathrm{SD} /$ mean $\times 100$. Data were tested for normality and met assumptions for specific statistical procedures. Data were not transformed except for regression of $\mathrm{MeHg}$ against $\delta^{15} \mathrm{~N}$, when log-transformed data were used. Differences in stable isotopes and mercury content of the $>75 \mu \mathrm{m}$ PF among stations were determined by performing a nonparametric Wilcoxon's signed-rank test across paired sample dates (SYSTAT Software, Inc. 2004). Correlations among variables were determined using Pearson's pairwise correlations with Bonferroni probabilities (SYSTAT Software, Inc. 2004). Regression relationships between $\mathrm{MeHg}$ content of the $>75 \mu \mathrm{m}$ PF and other variables were determined using Sigma Plot and SYSTAT. The nonparametric analysis of variance (ANOVA) Kruskal-Wallis test was used to determine the differences in unfiltered $\mathrm{MeHg}$ among time periods, since 2 out of 24 values for unfiltered $\mathrm{MeHg}$ were below detection (Helsel 2005). These two nondetectable values were completely removed from the analysis when building the multiple linear regression between unfiltered $\mathrm{MeHg}$ in water and proportion of cladoceran biomass and $\mathrm{MeHg}$ content of the $>75 \mu \mathrm{m}$ PF. To compare stable isotope ratios among all biota to determine food web structure, we used the spring SPM and spring $>75 \mu \mathrm{m}$ PF data, together with the one-time data for the summer-collected benthic invertebrates and fish. This allowed for a more ecologically relevant comparison than if $>75 \mu \mathrm{m}$ PF data from the entire year were averaged; the availability of zooplankton varied throughout the year, yet analysis of fish gut contents indicated that fish relied on zooplankton during periods of highest abundance (spring). Regression relationships among $\delta^{15} \mathrm{~N}$ and mercury content (log-transformed) of the food web were evaluated using Sigma Plot and analysis of covariance (ANCOVA) in SYSTAT. Significance was accepted at an alpha level of $p=0.05$.

\section{Results and discussion}

\section{Phytoplankton biomass and quality of SPM}

Phytoplankton biomass and changes in the biochemical quality of the SPM suggest there was a shift in food available to zooplankton among different seasons. Phytoplankton biomass showed a strong seasonal cycle that was independent of water storage (Fig. $2 a$, Table 1). For example, chlorophyll $a$ concentrations in surface water were highest (mean value of $13 \pm 5.4 \mu \mathrm{g} \cdot \mathrm{L}^{-1}$ ) in the fall and winter as water levels rose and lowest $\left(3.5 \pm 0.90 \mu \mathrm{g} \cdot \mathrm{L}^{-1}\right)$ in the spring and summer as water levels declined. The peak in chlorophyll concentrations during fall of both years occurred at low water while the reservoir was thermally stratified (Alpers et al. 2008) and was generally sustained as the reservoir filled. The development of the bloom prior to destratification was not expected, since algal blooms typically occur when nutrients are mixed from the deep portions of the reservoir into surface waters following destratification, particularly in oligotrophic systems such as CFWR (N:P ratios of 136 to 5191; Kuwabara et al. 2003). Instead, phosphorus concentrations in inflowing water, which also peaked in the fall, probably stimulated the fall CFWR phytoplankton bloom (Alpers et al. 2008). In the fall of 2001 and 2002, chlorophyll $a$ concentrations were highest at the upstream BRA site and lowest at the downstream ND site, further suggesting an upstream rather than hypolimnetic source of nutrients. Pheophytin pigments followed a seasonal cycle similar to chlorophyll, which is consistent with the phytoplankton being consumed by zooplankton (Glooschenko et al. 1972; Poister et al. 1999). The ratio of chlorophyll $a /$ (chlorophyll $a+$ pheophytin), which is a general indicator of the proportion of chlorophyll in the water column that is photosynthetically active, was high, increasing from $0.76 \pm 0.028( \pm 1 \mathrm{SD})$ in the fall of 2001 to $0.87 \pm 0.028$ in April of 2002 and then declining to $0.70 \pm 0.06$ in August of 2002 and remaining constant through January 2003 (Table 1). These elevated ratios ( $>50 \%$ chlorophyll $a$ ) indicate that the phytoplankton community was actively growing and that cells degraded through zooplankton grazing were being rapidly removed from the water column, although measurement of pigment sedimentation rates would be required to confirm removal via grazing (Wetzel 2001).

The biochemical quality of the SPM varied seasonally and interannually, but was specifically similar among locations in the reservoir. Carbon isotopic ratios $\left(\delta^{13} C\right)$ of the SPM were similar among stations (Table 1 , mean CV across stations for all sample dates $2.6 \%$ ), but showed large seasonal and interannual differences. Values ranged from $-34 \% \pm$ $0.3 \%$ in February 2002 to $-28 \%$ o $\pm 0.5 \%$ in April 2002 (Table 1). Nitrogen isotopic ratios $\left(\delta^{15} \mathrm{~N}\right)$ of the SPM were more variable among stations (Table 1, 15\% CV) and ranged from a high of $8.22 \% \pm 2.1 \%$ in February 2002 to a low of $-2.46 \%$. $2.43 \%$ in April 2002 (Table 1). Carbon 
Fig. 2. Seasonal trends in chlorophyll $a$, zooplankton community, and $\mathrm{MeHg}$ content of $>75 \mu \mathrm{m}$ particulate fraction (PF) in Camp Far West Reservoir in relation to water storage. (a) Phytoplankton biomass (mean chlorophyll $a$ in $\mu \mathrm{g} \cdot \mathrm{L}^{-1} \pm$ standard deviation (SD); $n=$ 2 replicates) and reservoir storage (millions of $\mathrm{m}^{3}$, grey shaded area). (b) Zooplankton biomass $\left(\mu \mathrm{g} \cdot \mathrm{m}^{-3}\right)$ and $(c)$ proportional contribution of major zooplankton taxonomic groups (cladocerans, black; copepods, grey; rotifers, white) to total zooplankton biomass based on reservoir means ( $n=3-4$ stations). (d) Zooplankton $\mathrm{MeHg}$ content (ng. $\mathrm{g}^{-1}$ dry weight of $>75 \mu \mathrm{m}$ PF).
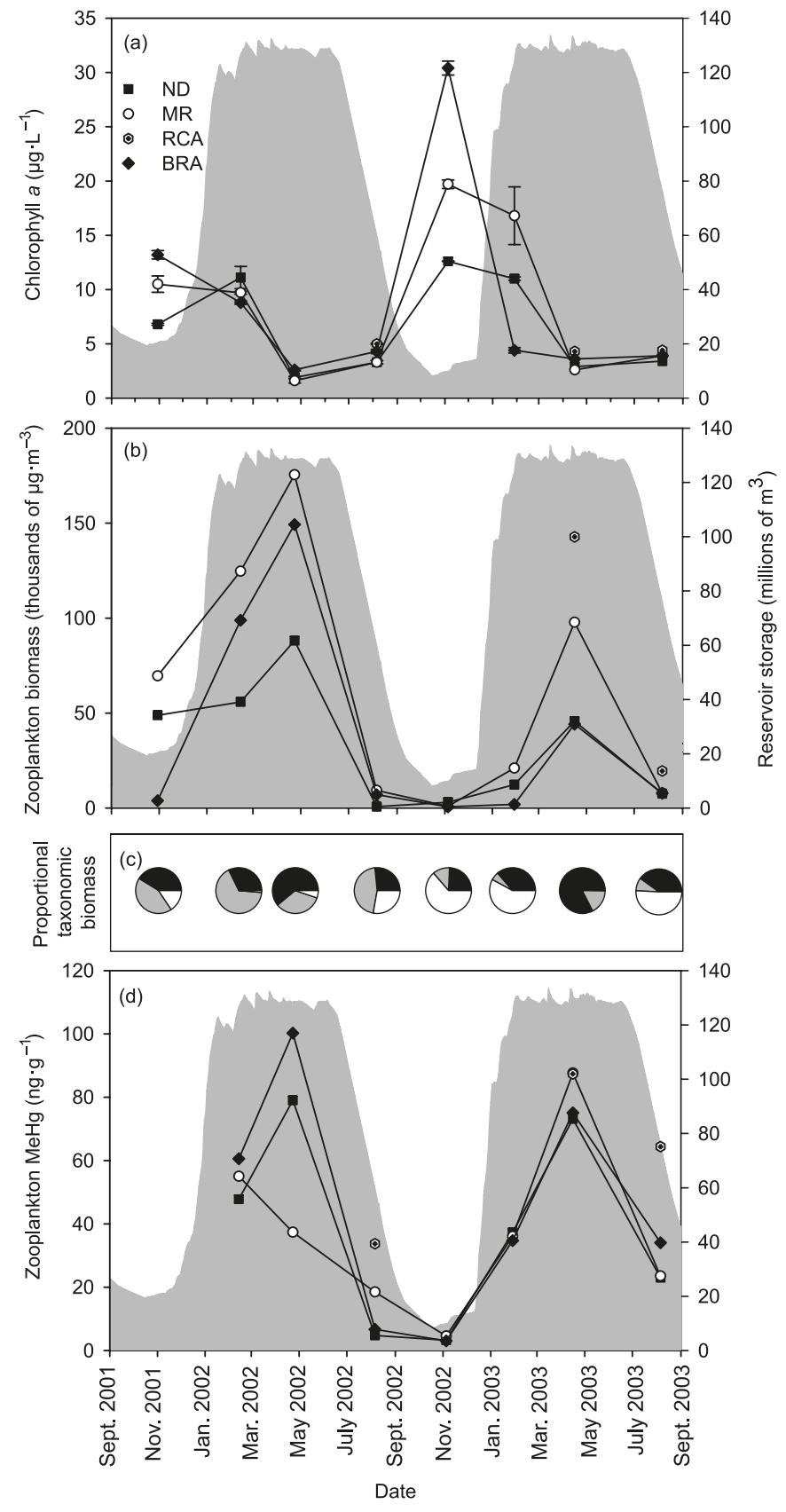

and nitrogen isotopes for all stations in fall, winter, and spring were significantly negatively correlated (Pearson's $r^{2}=$ $-0.68, p=0.001)$, whereas in the summer SPM $\delta^{13} \mathrm{C}$ and $\delta^{15} \mathrm{~N}$ were positively correlated (Pearson's $r^{2}=0.76, p=$ 0.028). The absolute value, range, and pattern of enriched nitrogen isotopic values coincident with depleted carbon isotopic values observed in CFWR across seasons is typical of the water columns in a range of freshwater lakes of varying trophic status (Vander Zanden and Rasmussen 1999). The reverse relationship in the summer, prior to the fall phytoplankton bloom, suggests that the composition and (or) source of the SPM were distinctly different than at other times of year. Similar to the isotopic trends, C:N ratios of the SPM did not vary significantly among seasons or stations $(16 \% \mathrm{CV})$ and were generally low $(<9)$, suggesting a phytoplankton-rich SPM (near-Redfield proportions of 6.6; Wetzel 2001) (Table 1). Indeed, epilimnetic phytoplankton was estimated to comprise on average $30 \%$ to $60 \%$ of the particulate organic carbon (Table 1). But again, the exception was during the summer of 2003 when $\mathrm{C}: \mathrm{N}$ ratios increased at all four stations to 19. Allochthonous carbon sources (e.g., inorganic particles, detritus including bacteria) rather than autochthonous carbon may have dominated CFWR SPM in the summer when water storage was low. Similar enriched values of $\delta^{13} \mathrm{C}$ were used to estimate allochthonous contributions to fine particulate matter in a range of natural lakes and flooded reservoirs in boreal environments (Montgomery et al. 2000).

\section{Zooplankton biomass, species, and biochemical composition of $>75 \mu \mathrm{m}$ PF}

Zooplankton biomass and species composition varied with the seasonal cycle of reservoir storage and the changes in food abundance and quality described above (Figs. $2 b-2 d$, Table 1). Zooplankton biomass peaked at maximum reservoir storage following the phytoplankton bloom and crashed during the summer and fall when reservoir levels were low and phytoplankton biomass was either depleted or increasing. There was significant variation among stations (Table 1) during periods of high biomass (CV range $0.33 \%-0.91 \%$ for all sites for a given season and year), but overall these differences were less than those observed among sample times (CV range $0.95 \%-1.28 \%$ for all seasons for a given site and year). The composition of the zooplankton community varied seasonally and with reservoir storage (Fig. 2c, Table 1). Similar to other lakes and reservoirs, cladoceran and copepod species dominated the community following flooding in the winter and in spring following the algal bloom (Paterson et al. 1997). When temperatures increased and food abundance and quality declined between spring and summer, the community became dominated by rotifers. In addition to phytoplankton, rotifers can utilize additional food resources such as bacteria and small protists, which may have allowed them to dominate during the summer; however, a decline in mesoplankton abundance and, thus, predation may have contributed to the shift in species composition (Yoshida et al. 2003).

The isotopic composition of the bulk $>75 \mu \mathrm{m}$ PF or zooplankton fraction varied considerably among sample times, with samples being slightly more depleted in ${ }^{13} \mathrm{C}$ and enriched in ${ }^{15} \mathrm{~N}$ in the fall and winter compared with the spring and summer. The $\delta^{13} \mathrm{C}$ of the $>75 \mu \mathrm{m}$ PF ranged from low values of $-33 \%$ o $\pm 2.4 \%$ o (mean $\pm 1 \mathrm{SD}$ ) in the fall and winter to heavier values of $-26 \% \pm 0.90 \%$ in the summer (Table 1). Conversely, $\delta^{15} \mathrm{~N}$ values ranged from a mean of $11 \% \pm 1.6 \%$ in the winter and fall and then declined to lows of $5.1 \%$ o $0.01 \%$ in the summer (Table 1 ). The carbon 
Table 1. Water chemistry and plankton in Camp Far West Reservoir.

\begin{tabular}{|c|c|c|c|c|c|c|c|c|}
\hline & \multicolumn{2}{|l|}{ Fall } & \multicolumn{2}{|l|}{ Winter } & \multicolumn{2}{|l|}{ Spring } & \multicolumn{2}{|l|}{ Summer } \\
\hline & 2001 & 2002 & 2002 & 2003 & 2002 & 2003 & 2002 & 2003 \\
\hline$N=$ stations-samples & 3 & 3 & 3 & 3 & 3 & 4 & 4 & 4 \\
\hline Chlorophyll $a\left(\mu \mathrm{g} \cdot \mathrm{L}^{-1}\right)$ & $10(3.2)$ & $21(8.5)$ & $9.8(1.1)$ & $11(6.3)$ & $2.0(0.51)$ & $3.4(0.76)$ & $4.0(0.83)$ & $3.9(0.41)$ \\
\hline Chlorophyll $a /$ (chlorophyll $a+$ pheophytin) & $0.76(0.028)$ & $0.65(0.021)$ & $0.82(0.006)$ & $0.64(0.024)$ & $0.87(0.028)$ & $0.83(0.066)$ & $0.70(0.060)$ & $0.79(0.035)$ \\
\hline Particulate organic carbon $\left(\mu \mathrm{g} \cdot \mathrm{L}^{-1}\right)$ & $1197(332)$ & $1806(939)$ & $713(99)$ & $611(261)$ & $231(41)$ & $305(38)$ & $484(54)$ & $394(75)$ \\
\hline Percentage of $\mathrm{C}$ as phytoplankton (\%) & $30(9.1)$ & $43(7.5)$ & 49 (12) & $59(12)$ & $31(3.3)$ & $38(4.2)$ & $29(3.0)$ & $36(7.9)$ \\
\hline Total suspended solids $\left(\mathrm{mg} \cdot \mathrm{L}^{-1}\right)$ & - & $13(2.7)$ & - & $3.0(1.2)$ & - & $0.87(0.52)$ & $17(6.4)$ & $3.0(1.3)$ \\
\hline $\mathrm{SPM} \delta^{13} \mathrm{C}$ & $-30.89(0.20)$ & $-30.70(1.2)$ & $-33.52(0.29)$ & $-29.73(0.41)$ & $-28.21(0.45)$ & $-28.55(1.9)$ & $-28.08(0.7)$ & $-26.00(0.81)$ \\
\hline SPM $\delta^{15} \mathrm{~N}$ & $6.01(1.1)$ & $3.24(0.76)$ & $8.22(2.1)$ & $5.85(2.4)$ & $2.91(0.88)$ & $1.86(0.63)$ & $-2.46(2.43)$ & $5.85(2.51)$ \\
\hline SPM C:N ratio & $8.22(0.32)$ & $8.70(0.51)$ & $6.27(0.17)$ & $9.49(1.13)$ & $8.04(0.83)$ & $10.59(0.97)$ & $9.38(0.57)$ & $19.26(1.78)$ \\
\hline Total ZP biomass $\left(\mu \mathrm{g} \cdot \mathrm{L}^{-1}\right)$ & $41(34)$ & $1.5(1.3)$ & $93(35)$ & $12(9.6)$ & $138(45)$ & $83(47)$ & $4.6(4.2)$ & $11(5.9)$ \\
\hline Cladoceran biomass $\left(\mu \mathrm{g} \cdot \mathrm{L}^{-1}\right)$ & $17(21)$ & $0.46(0.51)$ & $28(30)$ & $5.4(4.7)$ & $82(24)$ & $68(37)$ & $2.8(3.2)$ & $4.6(4.0)$ \\
\hline Copepod biomass $\left(\mu \mathrm{g} \cdot \mathrm{L}^{-1}\right)$ & $19(29)$ & $0.31(0.15)$ & $64(46)$ & $1.3(1.0)$ & $40(27)$ & $15(16)$ & $1.5(1.1)$ & $0.9(0.4)$ \\
\hline Rotifer biomass $\left(\mu \mathrm{g} \cdot \mathrm{L}^{-1}\right)$ & $4.3(2.9)$ & $0.9(0.6)$ & $1.1(0.54)$ & $5.4(4.5)$ & $6.8(1.6)$ & $0.26(0.15)$ & $0.97(1.1)$ & $5.1(2.3)$ \\
\hline $\mathrm{ZP} \delta^{13} \mathrm{C}$ & $-34.12(n=1)$ & $-29.39(3.28)$ & $-34.64(0.98)$ & $-33.22(0.51)$ & $-27.34(0.30)$ & $-31.84(0.17)$ & $-27.11(1.83)$ & $-25.83(0.77)$ \\
\hline $\mathrm{ZP} \delta^{15} \mathrm{~N}$ & $9.77(n=1)$ & $10.87(1.30)$ & $13.19(1.30)$ & $10.01(1.62)$ & $6.59(1.39)$ & $8.30(0.39)$ & $5.11(0.99)$ & $5.10(1.04)$ \\
\hline $\mathrm{ZP} \mathrm{C:N}$ ratio & $5.36(n=1)$ & $6.89(1.98)$ & $4.93(0.04)$ & $5.12(0.18)$ & $5.80(0.32)$ & $4.82(0.40)$ & $8.55(2.52)$ & $4.38(0.06)$ \\
\hline $\mathrm{ZP} \mathrm{MeHg}$ (ng.g ${ }^{-1}$ dry weight) & NS & $3.64(0.84)$ & $54.5(6.41)$ & $36.0(1.29)$ & $72.2(32.0)$ & $80.8(7.75)$ & $15.9(13.3)$ & $36.2(19.5)$ \\
\hline $\mathrm{ZP} \% \mathrm{MeHg}$ & NS & $0.95(0.41)$ & $39(4.2)$ & $21(7.1)$ & $68(17)$ & $66(11)$ & $8.6(4.9)$ & $35(13)$ \\
\hline $\mathrm{ZP} \log \mathrm{BAF}$ & NS & $4.80(0.148)$ & $5.99(0.128)$ & $5.78(0.089)$ & $5.92(0.196)$ & $5.95(0.092)$ & $5.32(0.478)$ & $5.84(0.191)$ \\
\hline
\end{tabular}

Note: Values are means ( \pm 1 standard deviation, SD) for stations Bear River arm, mid-Reservoir, near dam, and Rock Creek (only in spring 2003 and summer 2002-2003). SPM, suspended particulate material; ZP, particulate fraction $>75 \mu \mathrm{m}$; BAF, bioaccumulation factor $\left(\frac{\mathrm{ZP} \mathrm{MeHg}\left(\mathrm{ng} \cdot \mathrm{g}^{-1} \mathrm{dry} \text { weight }\right)}{\text { unfiltered MeHg }\left(\mathrm{ng} \cdot \mathrm{L}^{-1}\right)}\right)$; NS, no sample. 
Fig. 3. Variation in $\mathrm{MeHg}$ (ng. $\mathrm{g}^{-1}$ dry weight) with the proportion of cladoceran-specific $(a)$ and rotifer-specific $(b)$ biomass in the $>75 \mu \mathrm{m}$ particulate fraction.
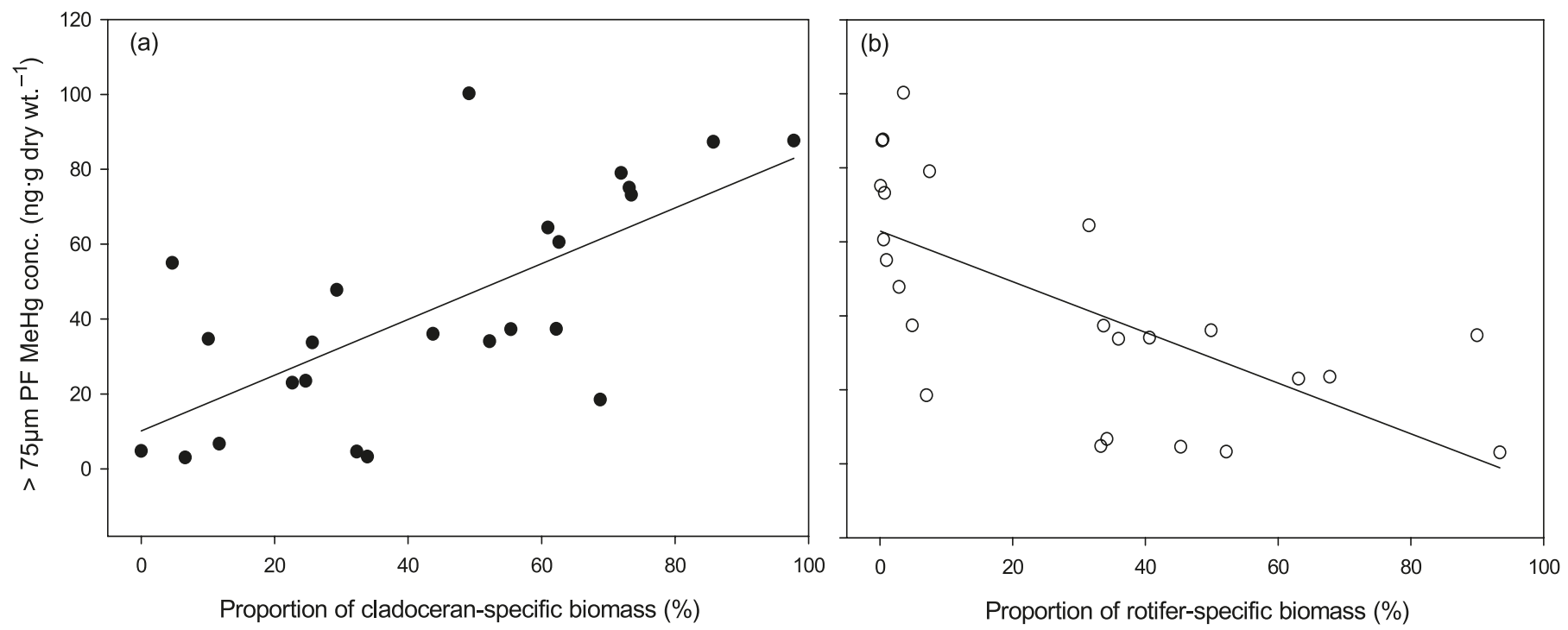

isotopic composition of the $>75 \mu \mathrm{m} \mathrm{PF}$ was significantly correlated to the carbon isotopic composition of the SPM $\left(r^{2}=0.601, p<0.0001\right)$. The $>75 \mu \mathrm{m}$ PF was on average (across all sample dates) depleted in ${ }^{13} \mathrm{C}$ by $\sim 0.98 \%$ o \pm $2.1 \%$ and enriched in $\delta^{15} \mathrm{~N}$ by $4.7 \%$ o $\pm 2.7 \%$ relative to the SPM, indicating the bulk $>75 \mu \mathrm{m}$ PF represents the next trophic link up from measured SPM and is likely dominated by zooplankton. Indeed, the average $\mathrm{C}: \mathrm{N}$ across all sample dates for the $>75 \mu \mathrm{m}$ PF was $5.73 \pm 1.37$, which is similar to the median $\mathrm{C}: \mathrm{N}$ ratio of invertebrate freshwater herbivores (6.0) determined by Elser et al. (2000) in a survey of more than 100 lakes. $\mathrm{C}: \mathrm{N}$ ratios of the $>75 \mu \mathrm{m}$ PF were generally similar among stations and sample times $(\mathrm{CV}<$ $10 \%$ ), except for the fall and summer of 2002, and ranged between 4.38 and 8.55 (Table 1). The slightly higher C:N ratios observed for $>75 \mu \mathrm{m} \mathrm{PF}$ in the summers of 2002 and 2003 might be indicative of the higher abundance of rotifers, capable of feeding on allochthonous carbon sources (also high in C:N ratios), although further species-specific sampling would be required to confirm this. Differences in C:N ratios and $\delta^{13} \mathrm{C}$ values have been reported for different large zooplankton species (i.e., Daphnia sp.) as well as temporal shifts in isotopic composition of individual zooplankters (i.e., changes in body lipid content; Matthews and Mazumder 2005); however, no values have been reported for rotifers. Alternatively, the higher $\mathrm{C}: \mathrm{N}$ ratios for the $>75 \mu \mathrm{m}$ $\mathrm{PF}$ in the summer may indicate that this fraction was contaminated with some non-zooplankton particles (e.g., inorganic particles, terrestrial material). However, we do not believe the contribution of the non-zooplankton particles to be substantial, particularly in the summer of 2003 when $>75 \mu \mathrm{m}$ PF $\mathrm{C}: \mathrm{N}$ ratios $(4.38 \pm 0.06)$ were almost 15 units lower than C:N SPM ratios (19.26 \pm 1.78$)$; indicating a distinctly different particle composition.

\section{MeHg content of $>75 \mu \mathrm{m}$ PF}

$\mathrm{MeHg}$ concentrations in the $>75 \mu \mathrm{m}$ PF were significantly correlated with zooplankton biomass, species composition, and in general reservoir storage, with concentrations peaking at maximum water levels. Mean $\mathrm{MeHg}$ concentrations in the $>75 \mu \mathrm{m}$ PF were not significantly different (Wilcoxon's signed-rank test, $p>0.05$ ) among sites within the reservoir (calculated for all sample dates), although values for the upstream BRA site tended to be higher than those at the other stations. Mean MeHg concentrations (average of all stations) in the $>75 \mu \mathrm{m}$ PF ranged from a low of $4 \mathrm{ng} \cdot \mathrm{g}^{-1}$ in the fall to $77 \pm 6.1 \mathrm{ng} \cdot \mathrm{g}^{-1}$ in the spring (Fig. $2 d$, Table 1). Conversely, the proportion of total mercury that was $\mathrm{MeHg}$ was highest in the spring $(67 \% \pm 13 \%)$ and lowest in the fall and winter $(20 \% \pm 18 \%)$ (Table 1$)$. MeHg concentrations in the $>75 \mu \mathrm{m}$ PF were in the range of concentrations observed for zooplankton in other natural lakes with predominantly atmospheric mercury sources (Montgomery et al. 2000; Back et al. 2003) and a peatland reservoir (Paterson et al. 1998), but did not reach concentrations measured in other artificially flooded reservoirs in Canada (>300 ng. ${ }^{-1}$, Paterson et al. (1998); Plourde et al. (1997)) or rivers in the San Francisco Bay-Delta (>100 ng.g ${ }^{-1}$; A. Stewart, unpublished data).

$\mathrm{MeHg}$ concentrations in $>75 \mu \mathrm{m}$ PF over time increased significantly with zooplankton biomass $\left(r^{2}=0.44, p=\right.$ 0.006) and, more specifically, with the proportion of cladoceran biomass relative to total biomass $\left(r^{2}=0.44, p=\right.$ 0.001) (Fig. 3a). Conversely, $\mathrm{MeHg}$ in $>75 \mu \mathrm{m} \mathrm{PF}$ decreased significantly with increasing inorganic mercury content of the $>75 \mu \mathrm{m}$ PF $\left(r^{2}=0.46, p=0.028\right)$ and with the proportion of rotifer biomass relative to total biomass $\left(r^{2}=\right.$ 0.45, $p<0.0001$ ) (Fig. 3b).

The increase in the $>75 \mu \mathrm{m}$ PF MeHg at high water storage could be explained by several processes associated with reservoir flooding, including an increase in $\mathrm{MeHg}$ exposure resulting from changes in concentration or bioavailability or by the shift in zooplankton species. Several lines of data suggest it is the latter process that is more critical in CFWR. Dissolved MeHg concentrations in the epilimnion of CFWR were uniformly low over the course of the study, which is surprising given the high loads of total mercury in the region, and generally were at or lower than the method 
detection limit of $0.04 \mathrm{ng} \cdot \mathrm{L}^{-1}$. Using regression on order statistics (Helsel 2005), the mean value and SD for all stations and dates was $0.04 \pm 0.014 \mathrm{ng} \cdot \mathrm{L}^{-1}(n=40 ; 50 \%$ of the values were below the method detection limit, see Alpers et al. (2008) for further details). These results are in stark contrast with those for an experimentally flooded boreal reservoir whose dissolved $\mathrm{MeHg}$ concentrations increased $>10$-fold from preflood concentrations of $0.1 \mathrm{ng} \cdot \mathrm{L}^{-1}$ (Kelly et al. 1997). Using the regression relationships between dissolved $\mathrm{MeHg}$ and $\mathrm{MeHg}$ in zooplankton for the above reservoir (Paterson et al. 1998), changes in dissolved MeHg concentrations of $0.02-0.04 \mathrm{ng} \cdot \mathrm{L}^{-1}$, below the detection limit, would only result in an increase in $\mathrm{MeHg}$ concentrations in zooplankton from 8 to $16 \mathrm{ng} \cdot \mathrm{g}^{-1}$ dry weight, which is considerably lower than the concentrations observed in CFWR in the spring. Concentrations of $\mathrm{MeHg}$ in unfiltered epilimnetic water from CFWR were highest in the spring (Kruskal-Wallis one-way ANOVA, $p=0.023$; Alpers et al. 2008), corresponding to maximum $\mathrm{MeHg}$ concentrations in the $>75 \mu \mathrm{m}$ PF; however, unfiltered $\mathrm{MeHg}\left(\mathrm{ng} \cdot \mathrm{L}^{-1}\right.$ ) was found to be a poor predictor of $\mathrm{MeHg}$ concentrations in the $>75 \mu \mathrm{m}$ PF compared with the proportion of cladoceran biomass (multiple linear regression $R^{2}=0.49, p=0.003$ for unfiltered $\mathrm{MeHg}$ and proportion of cladoceran biomass compared with $R^{2}=0.42, p=0.002$ for proportion of cladoceran biomass alone). Furthermore, calculated MeHg bioaccumulation factors (BAFs) for zooplankton relative to unfiltered water samples also ranked higher in the winter and spring when both unfiltered $\mathrm{MeHg}$ and $\mathrm{MeHg}$ in the $>75 \mu \mathrm{m} \mathrm{PF}$ were high, compared with the fall (Kruskal-Wallis one-way ANOVA, $p=0.014$ ) (Table 1). At low water levels, the mass of $\mathrm{MeHg}$ in the $>75 \mu \mathrm{m}$ PF accounted for less than $1 \%$ of the total mass of $\mathrm{MeHg}$ in unfiltered water, but increased to $7.1 \% \pm 4.6 \%$ at maximum zooplankton biomass and reservoir storage levels. Thus, the presence of uniformly low dissolved $\mathrm{MeHg}$ concentrations, higher unfiltered $\mathrm{MeHg}$ concentrations, and seasonal variation in BAFs that correspond with changes in total zooplankton biomass all suggest that the composition of the zooplankton community may have been an important driver of seasonal changes in $\mathrm{MeHg}$ in zooplankton (Figs. $2 b$ and 3). Greater bioavailability of $\mathrm{MeHg}$ in the SPM may have played a role in the higher $\mathrm{BAFs}$ and $\mathrm{MeHg}$ in zooplankton in the spring; however, similar to unfiltered $\mathrm{MeHg}$ concentrations, seasonal chlorophyll $a$ concentrations were not as good a predictor as zooplankton biomass of the $\mathrm{MeHg}$ content of the $>75 \mu \mathrm{m}$ PF.

It was not possible to ascertain the relationship between dissolved $\mathrm{MeHg}$ and $\mathrm{MeHg}$ in the $>75 \mu \mathrm{m}$ PF in CFWR because of the low aqueous concentrations. Nevertheless, the CFWR results differ from other studies of reservoirs that report detectable $\left(>0.04 \mathrm{ng} \cdot \mathrm{L}^{-1}\right)$ levels of dissolved $\mathrm{MeHg}$ and a simple relationship between unfiltered water and bulk zooplankton MeHg (Plourde et al. 1997; Paterson et al. 1998). In a small experimental boreal reservoir sampled biweekly over the ice-free season, Paterson et al. (1998) observed a rapid redistribution of $\mathrm{MeHg}$ among the aqueous dissolved fraction, the phytoplankton fraction (smaller particulates), and zooplankton fraction (large particulates), regardless of shifts in zooplankton species and biomass (Paterson et al. 1997). Important differences among these systems included an atmospheric vs. fluvial source of inorganic mercury, aqueous concentrations of $\mathrm{MeHg}$ that were 10-fold higher in the boreal reservoir, the reservoir was newly flooded, and water storage was relatively constant over the ice-free season. Further, the net size $(150 \mu \mathrm{m})$ used in this study likely underestimated rotifer biomass, and thus, shifts in rotifer biomass with changes in $\mathrm{MeHg}$ content of zooplankton would not have been detected.

Phytoplankton and zooplankton biomass have been shown to be negatively correlated with zooplankton $\mathrm{MeHg}$ in both experimental (Kidd et al. 1999; Pickhardt et al. 2002) and natural systems (Back et al. 2003). These studies report chlorophyll and aqueous mercury concentrations within the range of those observed in CFWR annually, yet our results indicate biodilution of $\mathrm{MeHg}$ was not a factor in CFWR. The concomitant increase in $>75 \mu \mathrm{m}$ PF MeHg and zooplankton biomass suggests that the pool of aqueous dissolved $\mathrm{MeHg}$ in CFWR was sufficiently large within the reservoir that depletion of $\mathrm{MeHg}$ did not occur. Otherwise a dilution of $\mathrm{MeHg}$ in the $>75 \mu \mathrm{m}$ PF might have been expected. In CFWR, the presence of large zooplankton species (i.e., cladocerans) appears to be a primary driver for elevated $\mathrm{MeHg}$ concentrations in $>75 \mu \mathrm{m} \mathrm{PF}$ in the spring. Indeed, higher concentrations of $\mathrm{MeHg}$ in larger zooplankton, particularly cladocerans, have been observed in other studies of natural lakes and reservoirs (Back and Watras 1995; Tremblay et al. 1998; Kainz et al. 2002) and in experimental exposures (Pickhardt et al. 2005). As suggested in Pickhardt et al. (2005), higher feeding, reproductive, and metabolic rates of cladocerans relative to the copepods and associated stoichiometric differences in essential macronutrients between these taxa may explain the differences observed; however, specific studies have yet to confirm this.

\section{Feeding relationships and trophic enrichment of $\mathrm{MeHg}$ in the CFWR food web}

Feeding relationships among biota in CFWR were complex because of seasonal changes in habitat and water level in the reservoir (Fig. 4). The only primary food source of the invertebrate consumers that was measured during the study was SPM (spring 2002: mean $\delta^{15} \mathrm{~N}=2.9 \%$, mean $\delta^{13} \mathrm{C}=-28.2 \%$ ). The food web consumer base was composed of pelagic zooplankton ( $>75 \mu \mathrm{m}$ PF, spring 2002; mean $\delta^{15} \mathrm{~N}=6.6 \%$, mean $\delta^{13} \mathrm{C}=-27.34 \%$ ) and benthic insects (mayfly nymphs: $\delta^{15} \mathrm{~N}=6.0 \%, \delta^{13} \mathrm{C}=-22 \%$; and midge larvae: $\delta^{15} \mathrm{~N}=7.7 \%, \delta^{13} \mathrm{C}=-22.3 \%$ ) and at half a trophic level higher were crayfish $\left(\delta^{15} \mathrm{~N}=8.9 \%\right.$, $\left.\delta^{13} \mathrm{C}=-21.2 \%\right)$. Threadfin shad $\left(\delta^{15} \mathrm{~N}=10.3 \%, \delta^{13} \mathrm{C}=\right.$ $-25.0 \%$ o $)$ and bluegill $\left(\delta^{15} \mathrm{~N}=11.4 \%, \quad \delta^{13} \mathrm{C}=-24.3 \%\right.$ ) formed the next trophic level, and spotted bass $\left(\delta^{15} \mathrm{~N}=\right.$ $14.2 \%, \delta^{13} \mathrm{C}=-23.5 \%$ o) was at the apex of the CFWR food web. Analysis of gut contents of the fish of CFWR further identified seasonal and ontogenetic variation in fish diets. Spotted bass were mostly piscivorous $(>80 \%$ by mass most seasons), with the exception of the summer when large bass (total length (TL) $>300 \mathrm{~mm}$ ) also consumed crayfish $(\sim 10 \%-50 \%$ by mass, with the importance of crayfish increasing with bass size) (Fig. 5). Both species of forage fish (bluegill and threadfin shad) were likely important food for the spotted bass. Bluegill was abundant year round, while threadfin shad was found in abundance in late spring through fall. In the spring, diet 
Fig. 4. Stable isotope plot showing trophic relationships of the Camp Far West Reservoir food web. Values are means $\pm 95 \%$ confidence interval. Data included spring-collected SPM (suspended particulate material) and ZP (zooplankton) $>75 \mu \mathrm{m}$ particulate fraction and summer-collected data including mayfly nymphs (MYN), midge larvae (MGL), crayfish (CRA, Orconectes virilis), threadfin shad (TFS, Dorosoma petenense), bluegill (BLG, Lepomis macrochirus), and spotted bass (SPB, Micropterus punctulatus).

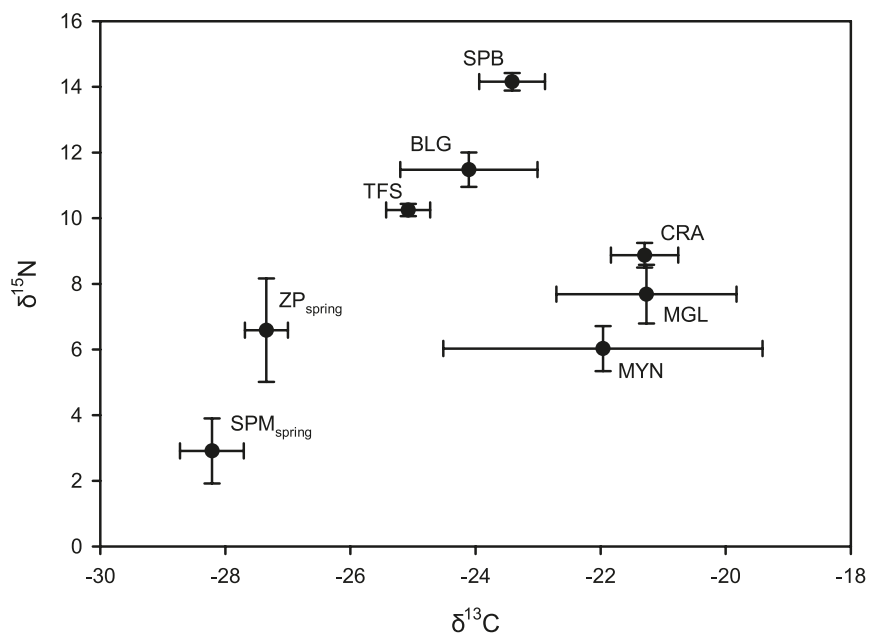

of the smaller bluegill (TL $<100 \mathrm{~mm}$; typically consumed by spotted bass, Lawrence 1961) included zooplankton and aquatic insects (Fig. 6). In summer, the smallest bluegill (TL $<50 \mathrm{~mm}$ ) continued to feed on zooplankton, but the larger individuals (TL 50-100 mm) were omnivorous, feeding on aquatic insects, detritus, plants, and some zooplankton. The gut contents of threadfin shad (data not shown) consisted mostly of detritus year round.

The relationship between trophic position (as inferred by $\delta^{15} \mathrm{~N}$ ) and $\mathrm{MeHg}$ for benthic and pelagic biota together is shown (Fig. 7). MeHg concentrations significantly increased with trophic position starting from SPM through spotted bass $\left(r^{2}=0.83, p<0.0001\right)$. The high coefficient of determination reflects the strong uniformity of mercury concentrations for a given trophic level independent of their habitat (benthic or pelagic). The slope of the relationship was $0.20 \pm 0.015$ (95\% confidence interval), indicating significant biomagnification of mercury through the food web. The slope was similar to those found (median $=0.23$, range $=$ $0.17-0.48, n=10$ food webs) for food webs (benthic and pelagic) in a wide range of aquatic systems (marine, freshwater) throughout the world (Kidd et al. 1995; Atwell et al. 1998; Campbell et al. 2005), suggesting that in general, processes controlling enrichment of $\mathrm{MeHg}$ with trophic position within the CFWR food web may be consistent with a wide range of aquatic systems having varied mercury sources imposed on varied biological assemblages. Indeed, studies of individual species suggest a strong degree of uniformity of $\mathrm{MeHg}$ uptake among biota of similar trophic levels (Pickhardt et al. 2006), further suggesting that differences among food webs would most likely be set by mercury availability at the base of the food web (i.e., $y$ intercept values).

Food web mercury content did vary spatially throughout the reservoir similar to the trends observed in SPM and zooplankton. Using ANCOVA, food web $\mathrm{MeHg}$ content was compared between the BRA and ND sites and was found to be $68 \%$ higher in the BRA food web (ANCOVA log $\mathrm{MeHg} \times \delta^{15} \mathrm{~N}, F=9.14, p=0.003$; mayfly nymphs were excluded from analysis since they were only dominant at the ND site).

\section{Influence of trophic pathway on $\mathrm{MeHg}$ bioaccumulation}

The sources of organic carbon fueling the food web were evaluated using stable isotopes to determine if the source of carbon and (or) trophic pathway influenced mercury accumulation in the food web. The carbon isotopic signatures of the SPM (spring $2002 \delta^{13} \mathrm{C}=-28.21 \% \pm 0.45 \%$; summer $2002 \delta^{13} \mathrm{C}=-28.08 \% \pm 0.70 \%$ ) and zooplankton (spring $2002 \delta^{13} \mathrm{C}=-27.34 \%$ $\pm 0.30 \%$ ) were similar and depleted relative to the benthic insects (summer 2002 $\delta^{13} \mathrm{C}=-21.57 \%$ $\pm 2.73 \%$ ) and crayfish (summer 2002 $\delta^{13} \mathrm{C}=-21.30 \% \pm 1.42 \%$ ), suggesting that pelagic phytoplankton was an important food source for zooplankton in the spring, but not necessarily for the benthic invertebrates in the summer (Fig. 4). Mayflies, midges, and crayfish sampled in CFWR were most likely herbivorous and (or) detritivorous, consuming a complex mixture of organic matter and detritus that settled from the water column (including senescing phytoplankton), decaying terrestrial or submerged aquatic vegetation or benthic algae growing on surface sediments. These carbon sources generally have enriched carbon isotopic values relative to pure phytoplankton (Hecky and Hesslein 1995; Cloern et al. 2002). The relative importance of these different carbon sources to the benthic organisms appeared to vary spatially within the reservoir. Stable carbon isotopic signatures for the benthic invertebrates were significantly more enriched in samples collected at ND than at BRA $(p<0.05)$. Mayflies and midges, collected from firm substrates at the ND site, were highly enriched $(-18.41 \% \pm$ $0.21 \%$ ) in ${ }^{13} \mathrm{C}$, which suggests these invertebrates may have been grazing on benthic algae. Statistically significant spatial differences in carbon isotopes were also found in higher trophic levels, with relative differences being the highest in bluegill $\left(\Delta=3.5 \%\right.$ o $\pm 2.2 \%$; propagated SD error for ${ }^{13} \mathrm{C}$ at both sites) followed by threadfin shad $(\Delta=2.2 \%$ $\pm 2.0 \%$ o and spotted bass $(\Delta=1.6 \%$ o $\pm 1.6 \%$ ). There were no significant spatial differences in carbon isotopes in zooplankton or SPM, which suggests the pelagic carbon source did not vary among sites.

The relative contributions of pelagic and benthic carbon sources to adult fish (1+ year) in CFWR were then calculated using stable isotopes. Stable carbon isotopes tend to show limited enrichment $(\sim 0.5 \% 0-1 \%$ ) with each increasing trophic level, and stable nitrogen isotopes show an enrichment of $\sim 3.4 \%$ (Peterson and Fry 1987; France 1995). After adjusting fish $\delta^{13} \mathrm{C}$ for a $0.5 \%$ onrichment in $\delta^{13} \mathrm{C}$ per trophic level increase above zooplankton and midge larvae $\left(\delta^{15} \mathrm{~N}=7.7 \%\right.$ ) , the proportions of pelagic carbon $\left(P_{\text {pelagic } \mathrm{C}}\right)$ in the top predators spotted bass and adult bluegill were calculated using the following equation modified from Hobson (1993):

$$
P_{\text {pelagic C }}=\frac{\delta^{13} \mathrm{C}_{\text {top predator }}-\delta^{13} \mathrm{C}_{\text {midge larvae }}}{\delta^{13} \mathrm{C}_{\text {zooplankton }}-\delta^{13} \mathrm{C}_{\text {midge larvae }}}
$$

Invertebrates (zooplankton and midge larvae) were used as 
Fig. 5. Gut contents of various sizes of spotted bass (Micropterus punctulatus) collected seasonally in Camp Far West Reservoir. Data were combined for samples collected in 2002 and 2003. Values above each bar indicate number of empty guts/total number of guts examined.

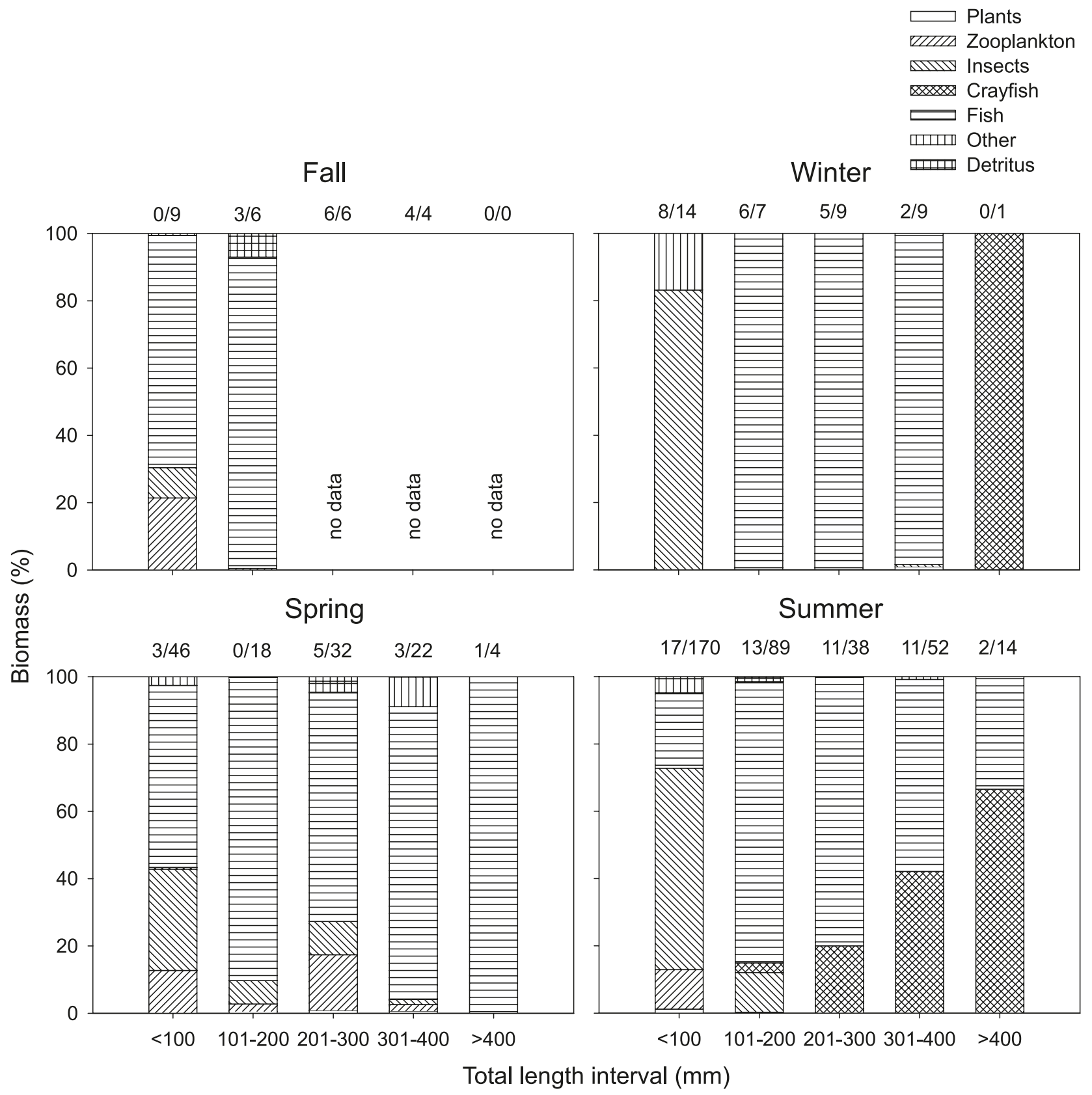

end-members of pelagic and benthic carbon sources, since only the pelagic algal source was measured. Because of the spatial differences in carbon isotopes, proportions were calculated separately for each of the food webs from the ND and BRA sites. The mean $P_{\text {pelagic C }}$ in individual adult bluegill, threadfin shad, and spotted bass at the BRA site were $0.78 \pm 0.39,0.82 \pm 0.32$, and $0.54 \pm 0.17$ and at the ND site were $0.51 \pm 0.13,0.68 \pm 0.078$, and $0.59 \pm 0.13$, respectively. Differences in proportions between sites were not statistically significant for any species, but overall the trends suggested a slightly greater dependence on pelagic carbon sources (i.e., $P_{\text {pelagic C }}$ for all fish $=0.69 \pm 0.06, n=68$ ), particularly for threadfin shad. When individual biota from both the BRA and ND sites were separated into those relying on pelagic carbon $\left(P_{\text {pelagic } \mathrm{C}}>0.50\right)$ and those relying on benthic carbon $\left(P_{\text {pelagic } \mathrm{C}}<0.50\right)$, the pelagic food web was found to have $70 \%$ more $\mathrm{MeHg}$ (least square means adjusted to a common $\delta^{15} \mathrm{~N}$ ) than the benthic food web (ANCOVA $F=9.32, p=0.004$; Fig. 8). Threadfin shad were excluded from the above analyses because of the major influence of length as a covariate after adjustment by $\delta^{15} \mathrm{~N}$. However, removal of this species had a limited impact on the overall results (with threadfin shad included, $\mathrm{MeHg}$ content of pelagic food web was $78 \%$ higher than the benthic food web; ANCOVA $F=21.5, p<0.0001$ ). Spotted bass did show a relationship between length and 
Fig. 6. Gut contents of various sizes of bluegill (Lepomis macrochirus) collected seasonally in Camp Far West Reservoir. Data were combined for samples collected in 2002 and 2003. Values above each bar indicate number of empty guts/total number of guts examined.

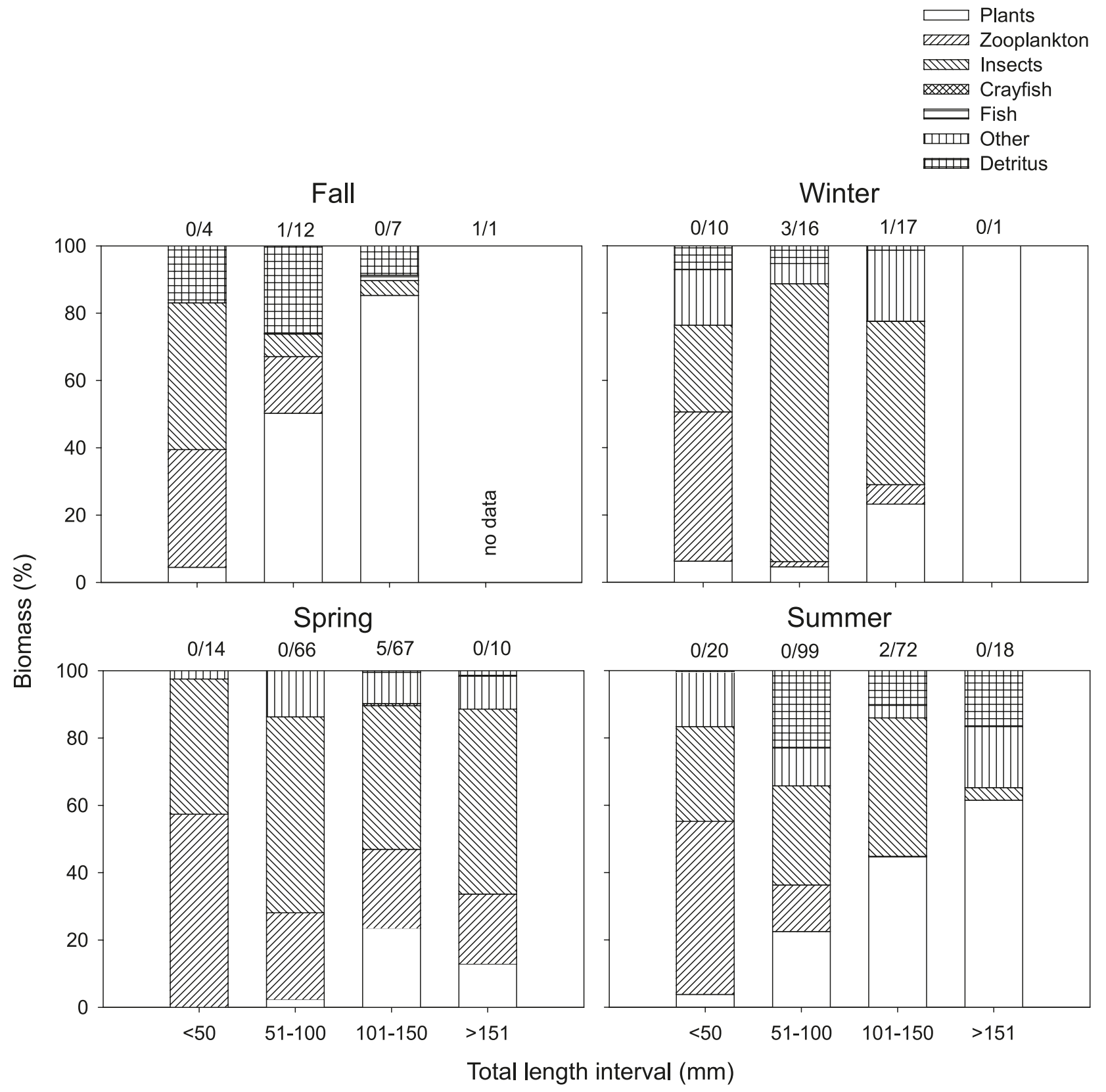

mercury content, but that relationship was removed by adjustment by $\delta^{15} \mathrm{~N}$.

\section{Importance of CFWR plankton dynamics in determining mercury burdens in top predator fish}

Physical and biological processes that varied as a function of CFWR water storage and flooding appeared to have several indirect effects on food quantity and quality and, as a result, zooplankton species composition, biomass, and $\mathrm{MeHg}$ content (Figs. 2 and 3). We recognize that further laboratory studies are required to develop direct causal relationships between zooplankton species composition and uptake of $\mathrm{MeHg}$; however, this and other studies suggest an important role for plankton dynamics in understanding
$\mathrm{MeHg}$ exposures in top predators. Our results suggest that mercury burdens in top predator fish might be influenced to a small, yet environmentally relevant, degree by management actions that modify or disrupt the plankton community in reservoirs that rely on plankton-based food webs, have extreme changes in water storage, and receive continued inputs of MeHg. However, the extent of the influence of the plankton dynamics on mercury concentrations in fish from CFWR requires careful consideration of processes at all trophic levels. Variation in plankton community over seasonal time scales did not result in an unusual pattern of trophic enrichment of mercury up the food chain. However, variation in the plankton community did have consequences for the quantity of $\mathrm{MeHg}$ entering the base of the pelagic food web 
Fig. 7. Relationship between trophic position $\left(\delta^{15} \mathrm{~N}\right)$ and $\log \mathrm{MeHg}$ content (ng. $\mathrm{g}^{-1}$ dry weight) of biota from Camp Far West Reservoir. Values plotted are means $\pm 95 \%$ confidence interval. Regression analysis ( $\pm 95 \%$ confidence intervals) is performed on raw data for individual biota. Data included spring-collected SPM (suspended particulate material - $\mathrm{MeHg}$ concentrations are adjusted to the proportion of phytoplankton in the sample, i.e., ng. $\mathrm{g}^{-1}$ phytoplankton $\mathrm{C}$ ) and $\mathrm{ZP}$ (zooplankton) $>75 \mu \mathrm{m}$ particulate fraction and summer-collected mayfly nymphs (MYN), midge larvae (MGL), crayfish (CRA, Orconectes virilis), threadfin shad (TFS, Dorosoma petenense), bluegill (BLG, Lepomis macrochirus), and spotted bass (SPB, Micropterus punctulatus).

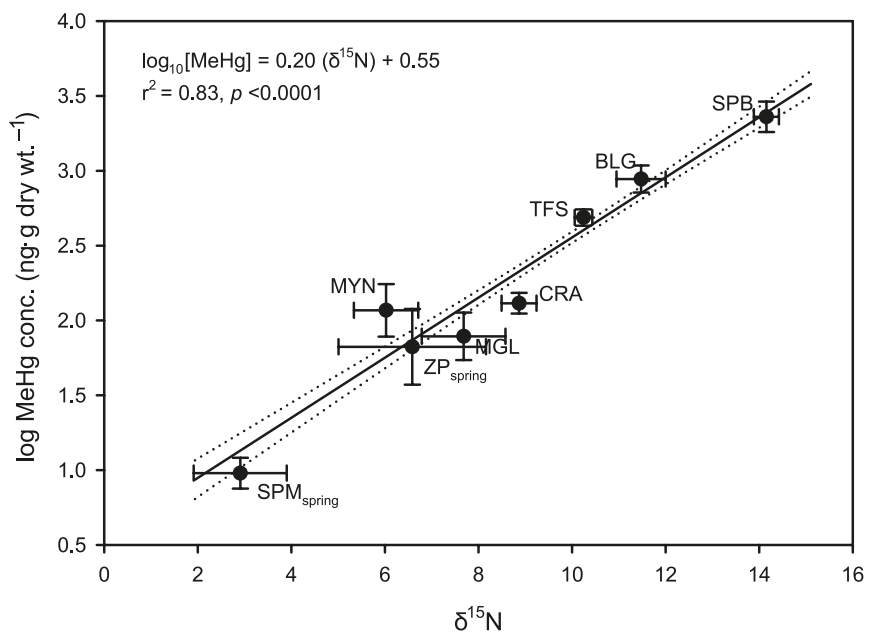

that is transferred to higher trophic levels. Fish that relied on pelagic carbon during times when $\mathrm{MeHg}$ concentrations in the $>75 \mu \mathrm{m}$ PF were the highest received maximal exposures. Dietary and stable isotopic evidence also suggests there is an important role for benthic organisms in mitigating $\mathrm{MeHg}$ exposure in top predators. For a given trophic level, benthic crayfish and midge larvae had lower $\mathrm{MeHg}$ concentrations than predicted from the food web relationship between $\log \mathrm{MeHg}$ and trophic position (Fig. 7; mean values fall below $95 \%$ confidence interval), which could explain the overall lower mercury concentrations in the benthicbased food web. However, mayfly nymphs showed higher than predicted $\mathrm{MeHg}$ concentrations, suggesting benthic exposures are heterogeneous and require more detailed investigation. Gorski et al. (2003) also report lower concentrations in adult yellow perch (Perca flavescens) and northern pike (Esox lucius) from a lake where there was a substantial contribution from benthic food sources, which also had lower relative $\mathrm{MeHg}$ concentrations compared with pelagic zooplankton. Enrichment of $\mathrm{MeHg}$ through the benthic food web was statistically similar to that of the pelagic food web (Fig. 8, slopes $\sim 0.2$ ), and so the differences in accumulation were determined at the base of the food web in CFWR. Why the benthic organisms were lower in $\mathrm{MeHg}$ might be explained by differences in $\mathrm{MeHg}$ speciation or bioavailability in their food. Detritus tends to have low nutritional value (i.e., high $\mathrm{C}: \mathrm{N}$ ratio, Elser et al. 2000) that can result in lower assimilation of nutrients and $\mathrm{MeHg}$ in invertebrate consumers compared with foods rich in algae and bacteria (Montgomery et al. 2000; Kainz and Mazumder 2005). We might also expect higher assimilation of $\mathrm{MeHg}$ from SPM
Fig. 8. Relationship between trophic position $\left(\delta^{15} \mathrm{~N}\right)$ and $\log \mathrm{MeHg}$ content (ng. $\mathrm{g}^{-1}$ dry weight) of the apparent pelagic ( $>50 \%$ pelagic carbon, open circles) and benthic $(<50 \%$ pelagic carbon, solid circles) food webs from Camp Far West Reservoir. Broken line represents the US Environmental Protection Agency's criterion for $\mathrm{MeHg}$ in fish tissue of $0.3 \mu \mathrm{g} \cdot \mathrm{g}^{-1}$ wet weight.

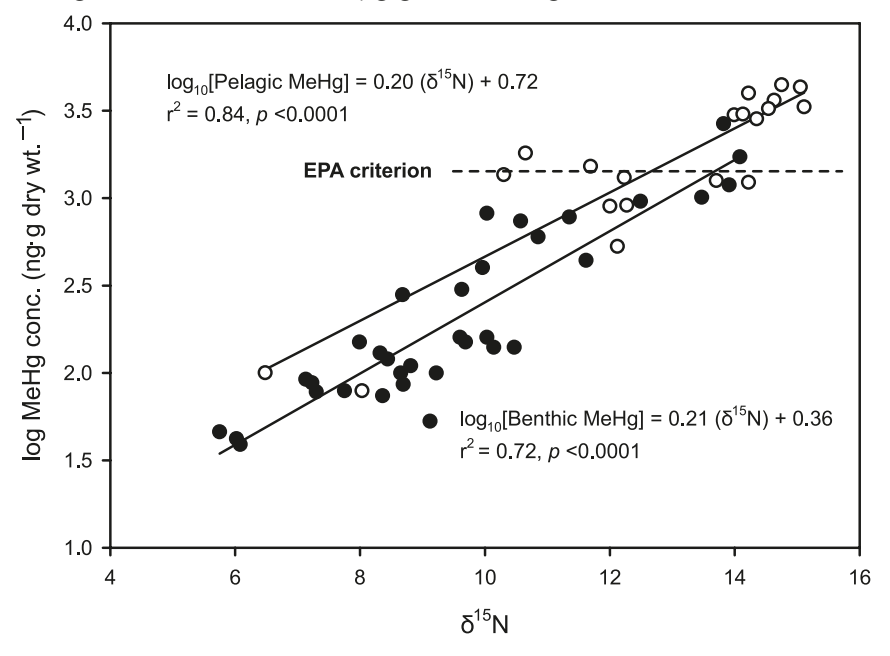

rich in phytoplankton because of the greater partitioning of $\mathrm{MeHg}$ in the cytoplasm of living phytoplankton, inferring a higher bioavailability relative to that bound to cell membranes, as observed for other elements (Reinfelder and Fisher 1991). However, further work on MeHg assimilation through benthic carbon sources is clearly warranted.

CFWR, impacted by elemental mercury used in gold refining, is physically, biologically, and chemically different from other reservoirs in the region and hence may require different management approaches to reduce mercury exposures than those used elsewhere. For example, seasonal plankton dynamics and spatial differences in $\mathrm{MeHg}$ in biota and food webs in CFWR point to an upstream source of $\mathrm{MeHg}$ to the reservoir. Further, low dissolved $\mathrm{MeHg}$ concentrations within the reservoir suggest the reservoir is not a source of $\mathrm{MeHg}$ to downstream food webs. In contrast, reservoirs and lakes in the Guadalupe River watershed, in close proximity to the New Almaden Mercury Mines in California, show hypolimnetic production of $\mathrm{MeHg}$ as a major source of $\mathrm{MeHg}$ to food webs both within the lake or reservoir as well as those downstream. Log BAFs calculated for unfiltered aqueous $\mathrm{MeHg}$ and zooplankton in CFWR and the Guadalupe watershed reservoirs (Kuwabara et al. 2005) were similar, which suggests broadly similar processes of enrichment from raw aqueous $\mathrm{MeHg}$ into phytoplankton and then zooplankton, regardless of the source of $\mathrm{MeHg}$. Thus, it is reasonable that a general management priority should be on identifying the source and reducing the quantity of aqueous $\mathrm{MeHg}$ that is initially accumulated at the base of reservoir food webs. However, in the case of CFWR where dissolved $\mathrm{MeHg}$ concentrations are already low, management priorities may shift toward a greater understanding of processes controlling uptake within the first two trophic levels. Manipulation of water levels in CFWR and changes in upstream nutrient inputs could affect the quality of the SPM, zooplankton abundance, and thus the contributions of pelagic carbon relative to benthic 
carbon to upper trophic levels. This shift in trophic structure may alter the assimilation efficiency of $\mathrm{MeHg}$ at the base of the food web and the quantity of $\mathrm{MeHg}$ that ultimately is incorporated in top predator fish. Indeed, for a given trophic level in CFWR, fish that relied on pelagic carbon exceeded the EPA fish tissue criterion of 0.3 parts per million wet weight more times than those relying on benthic carbon (Fig. 8).

As opposed to other metals, trophic transfer of $\mathrm{MeHg}$ is more related to its chemical speciation (Luoma and Rainbow 2005). Efflux rates are insignificant in determining organism-specific body burdens (Wang et al. 1998; Pickhardt et al. 2006). Other physiological processes such as assimilation efficiency and feeding rate can explain differences in $\mathrm{MeHg}$ bioaccumulation among invertebrate species and between invertebrates and fish. However, enrichment factors among trophic levels are relatively consistent. Further, the form of molecular complexes with $\mathrm{MeHg}$ in fish tissue appears to be uniform over a range of ecological settings and exposure conditions (Kuwabara et al. 2007). Thus, processes that modify the quantity of aqueous $\mathrm{MeHg}$ available for uptake at the base of the food web and through the second trophic level (e.g., zooplankton) are critical in determining $\mathrm{MeHg}$ bioaccumulation at the top of the food webs.

In summary, mercury dynamics in the plankton-based food web of CFWR were strongly correlated with changes in food quality and availability and zooplankton community structure, which in turn appear to be driven by thermal stratification and water storage levels in CFWR and seasonal changes in tributary inputs. $\mathrm{MeHg}$ concentrations in zooplankton were highest in the spring following a phytoplankton bloom and when cladoceran zooplankton were the dominant taxonomic group. Mercury was strongly biomagnified through the CFWR food web and had a trophic enrichment factor (slope 0.20 ) very similar to other food webs in other systems throughout the world. Stable isotope analysis revealed significantly higher contributions of $\mathrm{MeHg}$ from pelagic carbon sources to predatory fish compared with the benthic base of food web. These results suggest an important role for plankton dynamics in determining seasonal variation in $\mathrm{MeHg}$ content of zooplankton and subsequently in modifying the extent of $\mathrm{MeHg}$ bioaccumulation in top predators in highly managed reservoirs. Lastly, it highlights the importance of evaluating processes of mercury bioaccumulation at all trophic levels.

\section{Acknowledgements}

This study was funded by the California State Water Resources Control Board, the US Geological Survey (USGS) Western Region, the USGS California Science Water Center, the USGS Cooperative Hydrology Program, and the USGS Toxic Substances Hydrology Program. We thank all those who assisted with sample collection, processing, and analysis, including John DeWild, Gerald Moon, Francis Parchaso, Melissa Farinha, Paul Gerrity, Mary Langsner, Barbara Martin, and Amy Story. Zooplankton taxonomy and biomass estimates were done by Jim Orsi. Samples were analyzed for total mercury by Tom May and others. Tom also arranged to have the MeHg determined by Brooks Rand, Seattle. We greatly appreciate review comments and scientific advice of
Samuel Luoma, Rick Humphries, Lisa Lucas, Marie-Noële Croteau, Janet Thompson, Jim Cloern, Tara Schrag, Terry Short, and two anonymous reviewers.

\section{References}

Alpers, C.N., Hunerlach, M.P., May, J.T., and Hothem, R.L. $2005 a$. Mercury contamination from historical gold mining in California. US Geological Survey, Sacramento, Calif. Fact Sheet 20053014.

Alpers, C.N., Hunerlach, M.P., May, J.T., Hothem, R.L., Taylor, H.E., Antweiler, R.C., DeWild, J.F., and Lawler, D.A. $2005 b$. Geochemical characterization of water, sediment, and biota affected by mercury contamination and acidic drainage from historical gold mining, Greenhorn Creek, Nevada County, California, 1999-2001. US Geological Survey, Sacramento, Calif. Sci. Invest. Rep. 2004-5251.

Alpers, C.N., Stewart, A.R., Saiki, M.K., Marvin-DiPasquale, M.C., Topping, B.R., Rider, K.M., Gallanthine, S.K., Kester, C.A., Rye, R.O., Antweiler, R.C., and DeWild, J.F. 2008. Environmental factors affecting mercury in Camp Far West Reservoir, 2001-03. US Geological Survey, Sacramento, Calif. Sci. Invest. Rep. 2006-5008. In press.

Atwell, L., Hobson, K.A., and Welch, H.E. 1998. Biomagnification and bioaccumulation of mercury in an arctic marine food web: insights from stable nitrogen isotope analysis. Can. J. Fish. Aquat. Sci. 55: 1114-1121. doi:10.1139/cjfas-55-5-1114.

Back, R.C., and Watras, C.J. 1995. Mercury in zooplankton of northern Wisconsin lakes: taxonomic and site-specific trends. Water Air Soil Pollut. 80: 931-938. doi:10.1007/BF01189747.

Back, R.C., Gorski, P.R., Cleckner, L.B., and Hurley, J.P. 2003. Mercury content and speciation in the plankton and benthos of Lake Superior. Sci. Total Environ. 304: 349-354. doi:10.1016/ S0048-9697(02)00580-6. PMID:12663195.

Bodaly, R.A., Hecky, R.E., and Fudge, R.J.P. 1984. Increases in fish mercury levels in lakes flooded by the Churchill River diversion, northern Manitoba. Can. J. Fish. Aquat. Sci. 41: 682691. doi:10.1139/f84-079.

Bodaly, R.A., Jansen, W.A., Majewski, A.R., Fudge, R.J.P., Strange, N.E., Derksen, A.J., and Green, D.J. 2007. Postimpoundment time course of increased mercury concentrations in fish in hydroelectric reservoirs of northern Manitoba, Canada. Arch. Environ. Contam. Toxicol. 53: 379-389. doi:10.1007/ s00244-006-0113-4. PMID:17728990.

Bowen, S.H. 1997. Quantitative description of the diet. In Fisheries techniques. Edited by B.R. Murphy and D.W. Willis. American Fisheries Society, Bethesda, Md. pp. 513-532.

Campbell, C.E., Knoechel, R., and Copeman, D. 1998. Evaluation of factors related to increased zooplankton biomass and altered species composition following impoundment of a Newfoundland reservoir. Can. J. Fish. Aquat. Sci. 55: 230-238. doi:10.1139/ cjfas-55-1-230.

Campbell, L.M., Norstrom, R.J., Hobson, K.A., Muir, D.C.G., Backus, S., and Fisk, A.T. 2005. Mercury and other trace elements in a pelagic Arctic marine food web (Northwater Polyna, Baffin Bay). Sci. Total Environ. 351-352: 247-263. doi:10. 1016/j.scitotenv.2005.02.043. PMID:16061271.

Clark, L.D. 1976. Stratigraphy of the north half of the Western Sierra Nevada metamorphic belt, California. US Geological Survey Prof. Pap. No. 923.

Cloern, J.E., Canuel, E.A., and Harris, D. 2002. Stable carbon and nitrogen isotope composition of aquatic and terrestrial plants of the San Francisco Bay estuarine system. Limnol. Oceanogr. 47: 713-729. 
DeWild, J.F., Olson, M.L., and Olund, S.D. 2002. Determination of methyl mercury by aqueous phase ethylation, followed by gas chromatographic separation with cold vapor atomic fluorescence detection. US Geological Survey Open-File Rep. 01-445.

Dumont, H.J., Van de Velde, I., and Dumont, S. 1975. The dry weight estimate of biomass in a selection of Cladocera, Copepoda and Rotifera from the plankton, periphyton and benthos of continental waters. Oecologia (Berl.), 19: 75-97. doi:10.1007/ BF00377592.

Elser, J.J., Fang, F.W., Denno, F.R., Dobberfuhl, R.D., Florin, A., Huberty, A., Interlani, S., Kilham, S.S., McCauley, E., Schulz, L.K., Siemann, H.E., and Sterner, R.W. 2000. Nutritional constraints in terresterial and freshwater food webs. Nature (London), 408: 578-580. doi:10.1038/35046058. PMID:11117743.

France, R.L. 1995. Differentiation between littoral and pelagic food webs in lakes using stable carbon isotopes. Limnol. Oceanogr. 40: $1310-1313$.

Glooschenko, W.A., Moore, J.E., and Vollenweider, R.A. 1972. The seasonal cycle of pheo-pigments in Lake Ontario with particular emphasis on the role of zooplankton grazing. Limnol. Oceanogr. 17: 597-605.

Gorski, P.R., Cleckner, L.B., Hurley, J.P., Sierszen, M.E., and Armstrong, D.A. 2003. Factors affecting enhanced mercury bioaccumulation in inland lakes of Isle Royale National Park, USA. Sci. Total Environ. 304: 327-348. doi:10.1016/S00489697(02)00579-X. PMID:12663194.

Hall, B.D., Bodaly, R.A., Fudge, R.J.P., Rudd, J.W.M., and Rosenberg, D.M. 1997. Food as the dominant pathway of methylmercury uptake by fish. Water Air Soil Pollut. 100: 13-24.

Hecky, R.E., and Hesslein, R.H. 1995. Contributions of benthic algae to Lake Food webs as revealed by stable isotope analysis. J. N. Am. Benthol. Soc. 14: 631-653. doi:10.2307/1467546.

Helsel, D.R. 2005. Nondetects and data analysis: statistics for censored environmental data. John Wiley and Sons, New York.

Hobson, K.A. 1993. Trophic relationships among high Arctic seabirds: insights from tissue-dependent stable-isotope models. Mar. Ecol. Prog. Ser. 95: 7-18.

Holm-Hansen, O., and Riemann, B. 1978. Chlorophyll a determination: improvements in methodology. Oikos, 30: 438-447. doi:10. 2307/3543338.

Johnston, T.A., Bodaly, R.A., and Mathias, J.A. 1991. Predicting fish mercury levels from physical characteristics of boreal reservoirs. Can. J. Fish. Aquat. Sci. 48: 1468-1475. doi:10.1139/f91174.

Kainz, M., and Mazumder, A. 2005. Effect of algal and bacterial diet on methyl mercury concentrations in zooplankton. Environ. Sci. Technol. 39: 1666-1672. doi:10.1021/es049119o. PMID: 15819223.

Kainz, M., Lucotte, M., and Parrish, C.C. 2002. Methyl mercury in zooplankton - the role of size, habitat, and food quality. Can. J. Fish. Aquat. Sci. 59: 1606-1615. doi:10.1139/f02-125.

Kelly, C.A., Rudd, J.W.M., Bodaly, R.A., Roulet, N.P., St. Louis, V., Heyes, A., Moore, T.R., Schiff, S., Aravena, R., Scott, K.J., Dyck, B., Harris, R., Warner, B., and Edwards, G. 1997. Increases in fluxes of greenhouse gases and methyl mercury following flooding of an experimental reservoir. Environ. Sci. Technol. 31: 1334-1344. doi:10.1021/es9604931.

Kidd, K.A., Hesslein, R., Fudge, R.J.P., and Hallard, K.A. 1995. The influence of trophic level as measured by $\delta^{15} \mathrm{~N}$ on mercury concentrations in freshwater organisms. Water Air Soil Pollut. 80: 1011-1015. doi:10.1007/BF01189756.

Kidd, K.A., Paterson, M.J., Hesslein, R.H., Muir, D.C.G., and Hecky, R.E. 1999. Effects of northern pike (Esox lucius) additions on pollutant accumulation and food web structure, as de- termined by $\delta^{13} \mathrm{C}$ and $\delta^{15} \mathrm{~N}$, in a eutrophic and an oligotrophic lake. Can. J. Fish. Aquat. Sci. 56: 2193-2202. doi:10.1139/ cjfas-56-11-2193.

Kuwabara, J.S., Alpers, C.N., Marvin-DiPasquale, M., Topping, B.R., Carter, J.L., Stewart, A.R., Fend, S.V., Parchaso, F., Moon, G.E., and Krabbenhoft, D.P. 2003. Sediment-water interactions affecting dissolved-mercury distributions in Camp Far West Reservoir, California. US Geological Survey, Menlo Park, Calif. Water Resour. Invest. Rep. 03-4140.

Kuwabara, J.S., Topping, B.R., Moon, G.E., Husby, P., Lincoff, A., Carter, J.L., and Croteau, M.-N. 2005. Mercury accumulation by lower trophic-level organisms in lentic systems within the Guadalupe River watershed, California. US Geological Survey Sci. Invest. Rep. 2005-5037.

Kuwabara, J.S., Arai, Y., Topping, B.R., Pickering, I.J., and George, G.N. 2007. Mercury speciation in piscivorous fish from mining-impacted reservoirs. Environ. Sci. Technol. 41: 27452749. doi:10.1021/es0628856. PMID:17533833.

Lawrence, J.M. 1961. Estimated lengths of various forage fishes spotted bass can swallow. Proc. Annu. Conf. Southeast. Assoc. Game Fish Comm. 15: 235-236.

Luoma, S.N., and Rainbow, P.S. 2005. Why is metal bioaccumulation so variable? Environ. Sci. Technol. 39: 1921-1931. doi:10. 1021/es048947e. PMID:15871220.

Mason, R.P., Reinfelder, J.R., and Morel, F.M.M. 1996. Uptake, toxicity, and trophic transfer of mercury in a coastal diatom. Environ. Sci. Technol. 30: 1835-1845. doi:10.1021/es950373d.

Matthews, B., and Mazumder, A. 2005. Temporal variation in body composition $(\mathrm{C}: \mathrm{N})$ helps explain seasonal patterns of zooplankton $\delta^{13}$ C. Freshw. Biol. 50: 502-515. doi:10.1111/j.1365-2427. 2005.01336.x.

May, J.T., Hothem, R.L., Alpers, C.N., and Law, M.A. 2000. Mercury bioaccumulation in fish in a region affected by historic gold mining: the south Yuba River, Deer Creek, and Bear River Watersheds, California, 1999. US Geological Survey, Sacramento, Calif. Open-File Rep. No. 00-367.

Miles, C.J., Moye, H.A., Phlips, E.J., and Sargent, B. 2001. Partitioning of monomethylmercury between freshwater algae and water. Environ. Sci. Technol. 35: 4277-4282. doi:10.1021/ es010792c. PMID:11718342.

Montgomery, S., Lucotte, M., and Cournoyer, L. 2000. The use of stable carbon isotopes to evaluate the importance of fine suspended particulate matter in the transfer of methylmercury to biota in boreal flooded environments. Sci. Total Environ. 261: 33-41. doi:10.1016/S0048-9697(00)00593-3. PMID:11036975.

Ostrofsky, M.L., and Duthie, H.C. 1980. Trophic upsurge and the relationship between phytoplankton biomass and productivity in Smallwood Reservoir, Canada. Can. J. Bot. 58: 1174-1180. doi:10.1139/b80-146.

Paterson, M.J., Findlay, D., Beaty, K.G., Findlay, W., Schindler, E.U., Stainton, M.P., and McCullough, G. 1997. Changes in the planktonic food web of a new experimental reservoir. Can. J. Fish. Aquat. Sci. 54: 1088-1102. doi:10.1139/cjfas-54-5-1088.

Paterson, M.J., Rudd, J.W.M., and St. Louis, V. 1998. Increases in total and methylmercury in zooplankton following flooding of a peatland reservoir. Environ. Sci. Technol. 32: 3868-3874. doi:10.1021/es9803431.

Peterson, B.J., and Fry, B. 1987. Stable isotopes in ecosystem studies. Annu. Rev. Ecol. Syst. 18: 293-320. doi:10.1146/annurev. es.18.110187.001453.

Pickhardt, P.C., Folt, C.L., Chen, C.Y., Klaue, B., and Blum, J.D. 2002. Algal blooms reduce the uptake of toxic methylmercury in freshwater food webs. Proc. Natl. Acad. Sci. U.S.A. 99: 44194423. doi:10.1073/pnas.072531099. PMID:11904388. 
Pickhardt, P.C., Folt, C.L., Chen, C.Y., Klaue, B., and Blum, J.D. 2005. Impacts of zooplankton composition and algal enrichment on the accumulation of mercury in an experimental freshwater food web. Sci. Total Environ. 339: 89-101. doi:10.1016/j. scitotenv.2004.07.025. PMID:15740761.

Pickhardt, P.C., Stepanova, M., and Fisher, N.S. 2006. Contrasting uptake routes and tissue distributions of inorganic and methylmercury in mosquitofish (Gambusia affinis) and redear sunfish (Lepomis microlophus). Environ. Toxicol. Chem. 25: 21322142. doi:10.1897/05-595R.1. PMID:16916033.

Plourde, Y., Lucotte, M., and Pichet, P. 1997. Contribution of suspended particulate matter and zooplankton to $\mathrm{MeHg}$ contamination of the food chain in midnorthern Quebec (Canada) reservoirs. Can. J. Fish. Aquat. Sci. 54: 821-831. doi:10.1139/ cjfas-54-4-821.

Poister, D., Armstrong, D.E., and Hurley, J.P. 1999. Influences of grazing on temporal patterns of algal pigments in suspended and sedimenting algae in a north temperate lake. Can. J. Fish. Aquat. Sci. 56: 60-69. doi:10.1139/cjfas-56-1-60.

Reinfelder, J.R., and Fisher, N.S. 1991. The assimilation of elements ingested by marine copepods. Science (Washington, D.C.), 251: 794-796. doi:10.1126/science.251.4995.794.

Rosenberg, D.M., Berkes, F., Bodaly, R.A., Hecky, R.E., Kelly, C.A., and Rudd, J.W.M. 1997. Large-scale impacts of hydroelectric development. Environ. Rev. 5: 27-54. doi:10.1139/er-5$1-27$.
St. Louis, V.L., Rudd, J.W.M., Kelly, C.A., Bodaly, R.A., Paterson, M.J., Beaty, K.G., Hesslein, R.H., Heyes, A., and Majewski, A.R. 2004. The rise and fall of mercury methylation in an experimental reservoir. Environ. Sci. Technol. 38: 1348-1358. doi:10.1021/es034424f. PMID:15046335.

SYSTAT Software, Inc. 2004. SYSTAT 11. SYSTAT Software, Inc., Richmond, Calif.

Tremblay, A., Lucotte, M., and Schetagne, R. 1998. Total mercury and methylmercury accumulation in zooplankton of hydroelectric reservoirs in northern Quebec (Canada). Sci. Total Environ. 213: 307-315. doi:10.1016/S0048-9697(98)00107-7.

Vander Zanden, M.J., and Rasmussen, J.B. 1999. Primary consumer $\delta^{13} \mathrm{C}$ and $\delta^{15} \mathrm{~N}$ and the trophic position of aquatic consumers. Ecology, 80: 1395-1404. doi:10.1890/0012-9658(1999) 080[1395:PCCANA]2.0.CO;2.

Wang, W.X., Stupakoff, I., Gagnon, C., and Fisher, N.S. 1998. Bioavailability of inorganic and methylmercury to a marine deposit feeding polychaete. Environ. Sci. Technol. 32: 2564-2571. doi:10.1021/es971034i.

Wetzel, R.G. 2001. Limnology: lake and river ecosystems. Academic Press, San Diego, Calif.

Yoshida, T., Urabe, J., and Elser, J.J. 2003. Assessment of 'topdown' and 'bottom-up' forces as determinants of rotifer distribution among lakes in Ontario, Canada. Ecol. Res. 18: 639-650. doi:10.1111/j.1440-1703.2003.00596.x. 